\title{
APLIKASI SISTEM INFORMASI KOPERASI SIMPAN PINJAM UNTUK KEANGGOTAAN PADA KOPERASI PEDAGANG PASAR CIRACAS (KOPPAS CIRACAS) DENGAN MENGGUNAKAN METODE EXTREME PROGRAMING BERBASIS ANDROID
}

\author{
Sri Rejeki \\ Fakultas Teknik Jurusan Teknik Informatika \\ Universitas Bhayangkara Jakarta Raya \\ srirejeki@dsn.ubharajaya.ac.id
}

\begin{abstract}
ION
Cooperatives are non-bank institution legal entities aimed at the welfare of its members, in the form of financial business that is currently developing in DKI Jakarta very often used as daily savings and loans for members, with regulations in the field of cooperatives in Law No. 25 of 1992 concerning cooperatives. With Android-based technology and websites commonly used in the development of financial technology, FINTECH is wanted to be able to help cooperative systems that make it easier and save time. Cooperative applications created using Android Studio as interfaces with extreme programming system methodology used by members can see the cooperative application menu displayed online as an effort to minimize the possibility of members coming directly to the cooperative. Display in the application to find out balances, incoming transactions, accounts receivable money transactions, withdrawal and recapitulation transactions. At the end of this thesis will be made a cooperative information system using a PHP program, MySQL Database and KOPPAS android-based savings and loan cooperative application.
\end{abstract}

Keywords: Information Systems, Services, Cooperatives, Android

\section{A. PENDAHULUAN}

Koperasi berasal dari kata cooperation (Latin) atau Cooperation (Inggris), atau Co-operatie (Belanda) dalam bahasa Indonesia diartikan sebagai bekerja bersama, atau bekerja sama, atau kerjasama. Menurut Sri Edi Swasono. koperasi adalah badan hukum yang berdasar atas kekeluargaan yang semua anggotanya terdiri dari perorangan atau badan hukum dengan tujuan untuk mensejahterakan anggotanya. Koperasi simpan pinjam adalah lembaga bukan bank yang berbentuk koperasi dengan kegiatan usaha menerima simpanan dan memberikan punjaman uang kepada para anggotanya dengan bunga yang serendahrendahnya. Berdasarkan uu nomor 17 tahun 2012 yang dimaksud dengan simpanan adalah Landasan kekeluargaan adalah untuk bertujuan mensejahterakan setiap anggota dengan peraturan dan ketentuan umum yang disertakan dalam koperasi sehingga kegiatan perkoperasian dapat berjalan dengan baik.simpanan adalah sejumlah uang yang disimpan oleh anggota kepada koperasi simpan pinjam, dengan memperoleh jasa dan koperasi simpan pinjam sesuai perjanjian. Namun sejak dibatalkannya uu no 17 tahun 2012 tetang perkoperasian oleh Mahkamah Konstitusi (MK) tanggal 29 mei 2014 maka regulasi dibidang perkoperasian kembali pada uu no 25 tahun 1992 tentang perkoperasian. 
Reminder saat ini digunakan sebagaimana sebuah sistem yang digunakan untuk mengingatkan anggota untuk mengontrol kegiatan koperasi atau tanda bukti selain dengan buku yang konfensional saat ini banyak digunakan dalam perusahaan atau organisasi tersebut. Pendaftaran diperlukan saat anggota memulai keikutsertaan dalam koperasi dengan bentuk form kertas yang tercetak dan tersimpan dalam kumpulan berkas, dengan format biodata keanggotaan dan penyetoran pertama. Setiap pengajuan akan di catat dalam laporan buku koperasi sehingga koperasi dan anggota dapat melihat dengan baik history transaksi keuangan tersebut. Sehingga proses dapat dilakukan dengan kertas atau mendata dengan kumpulan data setiap anggota. Laporan saldo yang berbentuk buku tabungan memerlukan cetakan buku dan mempunyai data tersebut dalam sistem, namun buku yang tersimpan dimiliki anggota dapat terselip ataubahkan hilang. Sehingga butuh bentuk yang meninggalkan kertas sebagai catatan laporan yang konfensional menjadi sebuah aplikasi perkembangan sistem informasi dapat sebagai alat untuk mencatatnya dengan berbentuk aplikasi yang menyediakan laporan saldo, pendaftaran, keanggotaan, sistem informasi koperasi.

Semakin banyak penguna smartphone yang ditawarkan saat ini membuat pengguna menjadi beralih dengan tawaran smartphone murah sehingga seluruh kegunaan dalam sebuah gadget dapat dilakukan dengan sekali genggaman dimana semua dapat dilakukan dengan mendownload aplikasi maupun interface yang mudah dipahami dengan keunggulan keunggulan tersebut pengguna smartphone menjadi bertambah tiap tahunnya.Menurut diatas penjualan smartphone global untuk pengguna akhir atau end-user penjualan smartphone berdasarkan sistem operasi meningkat dalam beberapa tahun belakangan jumlah penjualan tahun 2009 sebanyak 170 juta ponsel, pada tahun 2015 naik menjadi 1,4 miliar dan untuk tahun 2017 akan lebih bertambah lagi. Untuk saat ini pasar konsumen android sangat popular bagi pengguna smartphone menjadi barang wajib untuk digunakan dalam keseharian sehingga kemudahan dan efektifitas kerja dapat dilakukan dengan smartphone.

Pergerakkan startup di Indonesia terus berkembang dengan pesat yaitu $e$ commerce dan fintech pengertian sangatlah luas. E-commerce merupakan situs jual beli online, sedangkan Fintech lebih berpusat denga inovasi jasa keuangan dengan sentuhan teknologi modern. Jenisnya berbagai macam dari pengelolaan asset, e-money, payment gateway, saham, insurance, P2P Lending, asuransi dan berbagai macam lainnya. Pada dasarnya fintech memiliki sifat memudahkan transaksi melalui layanan yang simple, akses yang mudah serta dikemas dengan teknologi yang kekinian.

Sebagai solusi dari permasalahan diatas, maka penyajian aplikasi pelayanan informasi sangat menunjang untuk mengurangi permasalahan tersebut. Oleh karena itu penulis tertarik untuk membangun suatu sistem informasi Aplikasi Sistem Informasi Koperasi Simpan Pinjam Untuk Keanggotaan Pada Koperasi Pedagang Pasar Ciracas (KOPPAS CIRACAS) Dengan Menggunakan Metode Extreme Programing Berbasis Android"

\section{B. IDENTIFIKASI MASALAH}

Sesuai dengan latar belakang yang telah dikemukakan diatas, langkahlangkah selanjutnya dapat dirumuskan permasalahan yang dipilih sebagai berikut:

i. Pendaftaran keanggotaan koperasi 
sebagian belum memahami pra

persyaratan yang berlaku.

ii. kebutuhan akan informasi untuk

laporan saldo yang dimiliki setiap anggota.

iii. Kemajuan teknologi yang mampu mengemas informasi dalam sebuah sistem aplikasi yang berjalan.

\section{RUMUSAN MASALAH}

Bagaimana membuat pelayanan yang baik dalam penyajian sistem informasi pada anggota simpan pinjan serta kemajuan teknologi di bidang finansia dalam sistim koperasi.

\section{TUJUAN}

Berdasarkan rumusan masalah yang dikemukakan di atas dapat disebut mempunyai beberapa tujuan adalah :

i. Membuat anggota untuk mengetahui informasi dalam account anggota tersebut secara detail.

ii. Merancang sebuah sistem informasi agar dapat mengurangi kesalahan dalam proses pengolahan data hingga laporan.

\section{E. LANDASAN TEORI \\ 1. Pengertian Sistem}

Sistem didefinisikan sebagai kumpulan prosedur yang saling berkaitan dan saling terhubung untuk melakukan suatu tugas bersama- sama. Secara garis besar, sebuah sistem informasi terdiri atas tiga komponen mencakupi software, hardware, dan brinware yang berkaitan satu sama lain. ${ }^{2}$ Tata Sutabri, Analisis Sistem Informasi, Yogyakarta ANDI, 2012, hlm 6. Gordon B. Davis dalam bukunya bahwa sistem bisa berupa abstrack atau fisik sistem yang Abstrack adalah susunan gagasan-gagasan atau konsepsi yang teratur yang saling bergantungan sedangkan sistem bersifat fisik adalah serangkaian unsur yang bekerja sama untuk mencapai suatu tujuan.

\section{Pengertian Informasi}

Informasi adalah salah satu sumber daya pernting dalam suatu organisasi, digunakan sebagai dalam bahan pengambilan keputusan. Sehubungan dengan hal itu informasi harus berkualitas menurut Burch dan Grudnitski, kualitas informasi dibagi 3 yaitu: relevansi, tepat waktu, dan akurasi. 4 Ibid, hlm 546.

Informasi dapat diperoleh dengan baik dari berbagai media cetak maupun media elektronik, namun tidak sedikit dari informasi yang diperoleh juga salah dan menyesatkan dapat diterima dalam hal iini kita sebagai penikmat informasi juga harus lebih cerdas dan bijak untuk menerima sebuah informasi bagaimana informasi didapatkan dengan baik benar dan faktual. Informasi merupakan hasil pengolahan data dari satu atau berbagai sumber yang kemudian diolah sehingga nilai, arti, dan bermanfaat.

Sumber dari informasi adalah data, data merupakan kenyataan yang menggambarkan suatu kejadian serta merupakan suatu kesatuan yang nyata dan merupakan bentuk yang masih mentah sehingga perlu diolah dengan lebih lanjut melalui suatu model untuk menghasilkan informasi. Inforasi dibagi menjadi 3 bagian, yaitu:

1. Informasi Strategis. Informasi digunakan untuk mengambil keputusan jangka panjang, mencangkum informasi eksternal, rencana perluasan perusahaan, dan sebagainya.

2. Informasi Taktis. Informasi ini dibutuhkan mengambilkeputusan jangka menengah, seperti informasi tren penjualan yang dapat dimanfaatkan untuk menyusun rencana penjualan.

3. Informasi Teknis. Informasi ini 
dibutuhkan untuk keperluan operasional sehari-hari, seperti persediaan stok, retur penjualan, dan laporan kas harian. ${ }^{5}$ Ibid, hlm. 21.

\section{Fungsi dan Siklus Informasi}

Fungsi informasi adalah menambah pengetahuan atau mengurangi ketidak-pastian pemakai informasi. Informasi yang disampaikan kepada pemakai merupakan dari data yang dimasukkan kedalam pengolahan. Data merupakan bentuk mentah belum dapat bercerita banyak sehingga perlu diolah lebih lanjut. Data diolah dengan menggunakan suatu proses tertentu.

Data di tangkap menjadi input kemudian di proses melalui suatu model dan diteruskan sebagai output informasi agar lebih jelas siklus ini yaitu:

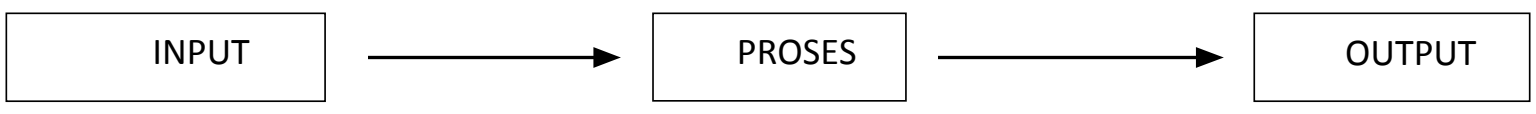

Gambar 2.1 Siklus Informasi

Sistem informasi bukan merupakan hal yang baru. Yang baru adalah komputerisasinya sebelum ada komputer, teknik penyaluran informasi yang memungkinkan manajer merencanakan serta mengendalikan operasi yang ada. Sistem informasi adalah suatu sistem didalam suatu organisasi yang mempertemukan kebutuhan pengolahan transaksi harian yang mendukung fungsi operasi organisasi yang bersifat manejerial dengan kegiatan strategi dari suatu organisasi untuk dapat menyediakan laporan- laporan yang diperlukan oleh pihak luar tertentu. 5 Ibid, hlm. 38. Definisi sistem informasi adalah gabungan dari empat bagian utama. Keempat macam perangkat lunak (software), perangkat keras (hardware), dan sumber daya manusia (SDM) yang terlatih. Dari komponen ini menciptakan sebuah sistem yang dapat mengolah data menjadi informasi yang bermanfaat. Didalammnya juga termasuk proses perencanaan, control, koordinasi, dan pengambilan keputusan. Maka sistem informasi merupakan sebuah sistem yang kompleks. ${ }^{6}$ I Putu Agus Eka Pratama, Sistem Informasi dan Implementasinya,
Bandung, Informatika, 2014, hlm. 10.

\section{Pengertian Koperasi}

Koperasi berasal dari kata cooperation (Latin) atau Cooperation (Inggris), atau Co-operatie (Belanda)dalam bahasa Indonesia diartikan sebagai bekerja bersama atau bekerja sama, atau kerjasama; Menurut Sri Edi Swasono. Perkembangan koperasi di DKI Jakarta mempunyai banyak perusahaan yang sudah memiliki koperasi untuk membuat karyawan kesejahteraan, dan dapat mengikuti tata kerja koperasi itu sendiri, koperasi adalah badan hukum yang berdasarkan atas kekeluargaan yang semua anggotanya terdiri dari perorangan atau badan hukum dengan tujuan mensejahterakan anggotanya. Setiap anggota memiliki tugas dan tanggung jawab masing-masing dimana setiap anggota mempunyai hak suara yang sama dalam setiap keputusan yang akan diambil.

Buku koperasi alat yang dapat dimiliki setiap anggota untuk mengetahui pelaporan bulanan saldo yang mereka miliki dan menjadi alat yang digunakan untuk pengajuan simpan pinjam untuk mensejahterakan anggota dalam 
bermasyarakat maupun kehidupan mereka. Gerakan koperasi adalah keseluruhan organisasi koperasi dan kegiatan perkoperasian yang bersifat terpadu menuju tercapainya cita-cita bersama koperasi.

Koperasi simpan pinjam adalah lembaga bukan bank yang berbentuk koperasi dengan kegiatan usaha menerima simpanan dan memberikan pinjaman uang kepada anggota dengan bunga yang serendah rendahnya. Undang-undang no 25 tahun 1992 landasan dan asas mengatur semua tentang perkoperasian untuk memertegas jatidiri, kedudukan, permodalan, danpembinaan koperasi, bagaimana aturan dalam sebuah koperasi dapat berjalan dengan baik dengan ketentuan yang diatur setiap pasalnya. Landasan utama terbentuknya koperasi adalah pancasila UUD 1945 dan serta didasar asas kekeluargaan. Bertujuan mensejahterakan anggota khususnya dan masyarakat pada umumnya serta ikut membangun tatanan perekonomian nasional dalam rangka mewujudkan masyarakat yang maju, adil, dan makmur berlandaskan Pancasila dan ndangundang dasar 1945. Membangun dan mengembangkan potensi dan kemampuan ekonomi anggota pada khususnya dan masyarakat pada umumnya untuk kesejahteraan ekonomi dan sosial serta aktif dalam upaya meningkatkan kualitas kehidupan manusia dan masyarakat sebagai dasar kekuatan ketahanan perekonomian nasional dengan koperasi sebagai sokogurunya yang berdasarkan asas kekeluargaan dan demokrasi ekonomi, memiliki prinsip koperasi untuk menyelenggarakan pendidikan perkoperasian dan kerja sama antar koperasi untuk mengembangkan koperasi, pembentukan koperasi dibagi menjadi 2 yaitu koperasi primer yang beranggotakan sekurang-kurangnya 20 (dua puluh) orang dan koperasi sekunder dibentuk sekurang-kurangnya 3 (tiga) koperasi, yang berarti pembentukan koperasi dengan pendirian yang memuat anggaran dasar. Anggaran dasar yang dimaksud adalah memuat daftar nama sendiri, nama dan tempat kedudukan, maksud dan tujuan serta bidang usaha, ketentuan-ketentuan lain yang mengatur mengenai keanggotaan, rapat anggota, pengelolaan, pemodalan, jangka waktu berdirinya, kepembagian sisa hasil usaha, dan sanksi. Koperasi memperoleh badan hukum akta pendirian dari pemerintah, jenis koperasi sidasarkan pada kesamaan kegiatan dan kepentingan ekomi anggotanya, anggota adalah pemilik sekaligus pengguna jasa koperasi dan dicatat dalam buku daftar anggota, setiap anggota memiliki hak tanggung jawab masing- masing diatur dalam aturan koperasi sehingga anggota dapat menaati aturan organisasi yang ada dikoperasi. Dalam organisasi koperasi nenili perangkat pengurus, pengawas dan rapat anggota. Dalam laporan tahunan memhitung tahunan akhir tahun buku yang baru lampau dan perhitungan hasil usaha bersangkutan serta menjelaskan atas dokumen keadaan dan koperasi serta sisa hasil usaha yang dapat dicapai. Modal koperasi terdiri dari modal sendiri berasal dari simpanan pokok, simpanan wajib, dana cadangan, hibah. Modal pinjaman dapat berasal dari anggota, koperasi lain dan/atau anggotanya, bank dan lembaga keuangan lainnya, penerbitan obligasi dan surat hutang lainnya., dan sumber sah lainnya. Usaha koperasi berkaitan langsung dengan kepentingan angggota, pelayanan koperasi dapat memenuhi kebutuhan masyarakat yang bukan anggota koperasi usaha simpan pinjam merupakan kegiatan penghimpun dana dan menyalurkan koperasi dengan kegiatan yang lebih lanjut dalam peratuan pemerintah. SHU (sisa hasil usaha) diperoleh dalam jangka 
waktu satu tahun di kurangi dengan biaya, penyusutan, dan kewajiban lainnya termasuk pajak dalam tahun buku yang bersangkutan dan sisa hasil usaha dibagikan kepada anggota. Pembubaran koperasi dapat dilakukan berdasarkan keputusan rapat anggota atau keputusan pemerintah, keputusan pemerintah dimaksud adalah terbukti koperasi bersangkutan tidak memenuhi ketentuan undang-undang ini, kegiatan bertentangan dengan ketentuan umum/ keasusilaan, kelangsungan hidup tidak dapat lagi diharapkan. Keputusan dikeluarkan dalam jangga paling lambat 4 bulan terhitung diterimanya tanggal surat pemberitahuan rencana pembubaran tersebut. Namun dalam jangga 2 bulan sejak penerimaan pemberitahuan koperasi berhak mengajukan keberatandan diterimanya atau tidak keberatan atas rencana pembubaran diberikan waktu 1 bulan sejak diterima eprnyataan keberatan tersebut, koperasi secara bersama-sama mendirikan satu organisasi tunggal yang berfungsi sebagai wadah memperjuangkan kepentingan dan bertindak sebagai pembawa aspirasi kopersi, beazaskan Pancasila dan segala sesuatu dalam kopersasi dan tata kerja organisasi diatur dalam anggaran dasar organisasi yang bersangkutan. ${ }^{7}$ Undangundang no. 25 tahun 1992 tentang perkoperasian.

\section{a. Konsep Dasar Pembuatan Web}

Web berasal dari website adalah suatu halaman web yang saling berhubungan yang umumnya berada pada rangkaian perangkat yang berisikan kumpulan informasi yang disediakan secara perorangan, kelompok atau organisasi. Halaman web merupakan berkas yang ditulis sebagai berkas teks biasa (plain text) yang diatur dikondisikan sedemikian rupa dengan instruksi-instruksi berbasis HTML atau XHTML. ( https://id.wikipedia.org/wiki/
Situs_web 301017 18.00)

\section{i. HTML}

HTTP (HyperText Transfer protokol) adalah sebuah protocol yang digunakan untuk membuat format dokumen web yang mampu dibaca dalam browser dari berbagai platform komputer. Adapun dokumen yang situlis dalam format HTML (HyperText Markup Langguage) dengan bentuk .HTM atau .HTML. dokumen ini diletakkan pada web server yang melayani permintaan halaman web dan dapat di akses oleh klien melalui perangkat lunak browser. 8 Abdul Khadir dan Terra $\mathrm{CH}$. Triwahyuni, Pengenalan Teknologi Informasi, Yogyakarta, ANDI, 2012, hlm. 460 .

\section{ii. $\quad$ PHP}

PHP merupakan bahasa pemrograman yang banyak digunakan untuk membuat web yang dinamis. PHP itu sendiri memiliki singkatan dari $P H P$ hypertext Processor. PHP adalah software yang bersifat open source dapat digunakan berbagai jenis platform sistem operasi, PHP dapat di sisipkan dalam skrip HTML untuk membuat web dinamis dengan cepat. 9 Frangky Rawung, buku pintar APLIKASI SMS dengan PHP dan MySQL, Yogyakarta, PENERBIT GAVA MEDIA, 2017, hlm. 23.

\section{iii. E-mail}

Electronic mail atau Email adalah sarana surat elektronik yang memungkinkan pengguna internet saling berkomunikasi dengan mengirim pesan. Rasanya hampir tidak mungkin pengguna internet belum memiliki email, terlebih pengguna android. Email juga dapat dikatakan sebagai hasil peradaban manusia modern dimana tidak terlepas dari aktivitas dan kegiatan sehari-hari manusia. 


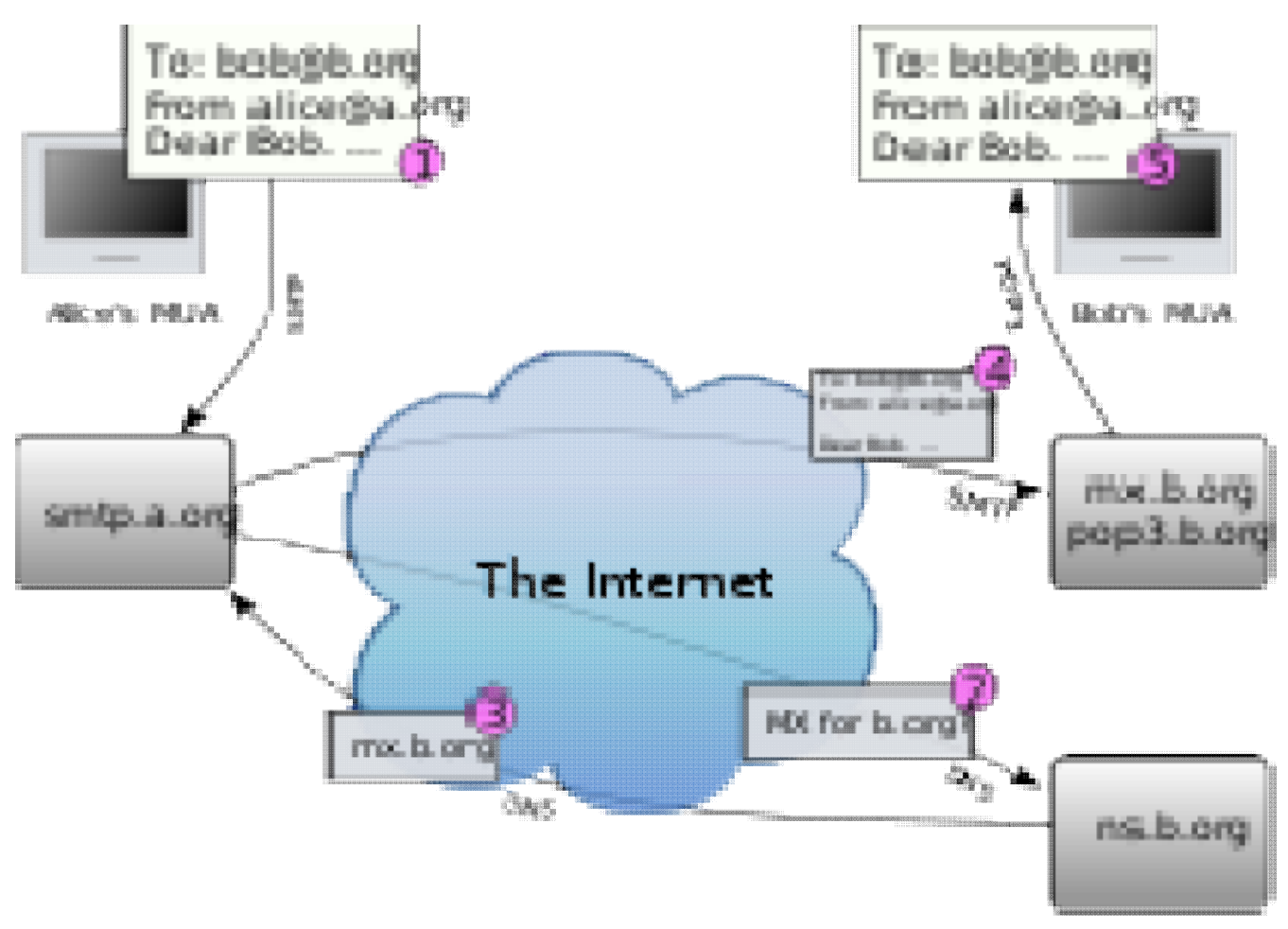

Gambar 2.5 Lima langkah dalam proses pengiriman surel

Dengan surat biasa umumnya pengirim perlu membayar per pengiriman (dengan membeli perangko), tetapi surat elektronik umumnya biaya yang dikeluarkan adalah biaya untuk membayar sambungan Internet. Tapi ada perkecualian misalnya surat elektronik ke telepon genggam, kadang pembayarannya ditagih per pengiriman.

\subsection{ANDROID}

Android adalah sistem berbasis linux yang dirancang untuk perangkat bergerak layar sentuh seperti telepon pintar (smartphone) atau komputer tablet. Awal nya dikembangkan oleh Android.Inc 2005 dengan dukungan ekonomi dari Google namun sejak 2007 Google membelinya bersamaan dengan didirikannya open handset alliance dengan opensource semua programer dapat membuat piranti lunak android dengan pengembangan dari pemrograman java dan pemrograman Android SDK dan penggunaan perangkat lainnya. banyak varian dalam sistem operasi ini dimulai dengan cupcake, donut, éclair, froyo, ginger bread, honercomb, jellybean, kitkat, lollipop, marsmallow, dan yang saat ini di rilis adalah nougat. Pengembangan sistem operasi menyediakan banyak fitur dengan aplikasi yang dapat di download dalam google play toko aplikasi utama Android, Yang dapat pengguna pasang dalam smartphone mereka.

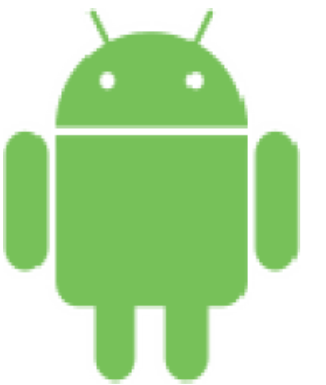

Gambar 2.7 Logo Android bersumber dari

https://id.wikipedia.org/wiki/Android_(si stem_operasi) 07112017 07:16 WIB 
Menjadi sistem operasi yang mudah dijalankan dan dipahami dengan tampilan sistem yang menarik sehingga berbagai macam aplikasi yang gratis maupun berbayar dapat langsung di download. Dengan berbagai macam aplikasi yang terinstal dalam smartphone membuat baterai cepat habis dan mengalami lemot atau lag karna kekurangan memori RAM dan prosesor.

Tabel 2.1 Perkembangan Sistem Operasi Android bersumber dari https://id.wikipedia.org/wiki/Android_(sistem_operasi) 10052018 01:47 WIB

\begin{tabular}{|c|c|c|c|c|}
\hline Versi & Nama kode & Tanggal rilis & Level API & Distribusi \\
\hline 7.0 & Nougat & $\begin{array}{l}22 \text { Agustus } \\
2016\end{array}$ & 24 & rang dari $0.1 \%$ \\
\hline 6.0 & Marshmallow & $\begin{array}{l}19 \text { Agustus } \\
2015\end{array}$ & 23 & \\
\hline $5 . x$ & Lollipop & $\begin{array}{l}15 \text { Oktober } \\
2014\end{array}$ & 21 & \\
\hline 4.4. $\mathrm{x}$ & KitKat ${ }^{[179]}$ & $\begin{array}{l}31 \text { Oktober } \\
2013[180]\end{array}$ & 19 & $24,5 \%$ \\
\hline 4.3.x & Jelly Bean & 24 Juli 2013 & 18 & $8 \%$ \\
\hline 4.2. $\mathrm{x}$ & Jelly Bean & $\begin{array}{l}13 \text { November } \\
2012\end{array}$ & 17 & $20,7 \%$ \\
\hline 4.1.x & Jelly Bean & 9 Juli 2012 & 16 & $25,1 \%$ \\
\hline $4.0 .3-4.0 .4$ & $\begin{array}{l}\text { Ice Cream } \\
\text { Sandwich }\end{array}$ & $\begin{array}{l}16 \text { Desember } \\
2011\end{array}$ & 15 & $9,6 \%$ \\
\hline 3.2 & Honeycomb & 15 Juli 2011 & 13 & \\
\hline 3.1 & Honeycomb & 10 Mei 2011 & 12 & \\
\hline $2.3 .3-2.3 .7$ & Gingerbread & $\begin{array}{l}9 \text { Februari } \\
2011\end{array}$ & 10 & $11,7 \%$ \\
\hline $2.3-2.3 .2$ & Gingerbread & $\begin{array}{l}6 \text { Desember } \\
2010\end{array}$ & 9 & \\
\hline 2.2 & Froyo & 20 Mei 2010 & 8 & $0,7 \%$ \\
\hline $2.0-2.1$ & Eclair & $\begin{array}{l}26 \text { Oktober } \\
2009\end{array}$ & 7 & \\
\hline 1.6 & Donut & $\begin{array}{l}15 \text { September } \\
2009\end{array}$ & 4 & \\
\hline 1.5 & Cupcake & 30 April 2009 & 3 & \\
\hline Versi & Nama kode & Tanggal rilis & Level API & Distribusi \\
\hline 7.0 & Nougat & $\begin{array}{l}22 \text { Agustus } \\
2016\end{array}$ & 24 & rang dari $0.1 \%$ \\
\hline
\end{tabular}

$\begin{array}{llll}\text { Android } & 6.0 & \text { dan } & 6.0 .1\end{array}$ merupakan "Marshmallow" pemutakhiran yang akan datang untuk sistem operasi telepon genggam Android, kemungkinan besar akan dirilis pada Q3 2015 ("sementara dijadwalkan untuk September"), 2$]$ dengan pratayang ketiga dan terakhir dirilis pada tanggal 17 Agustus 2015. Pertama diperkenalkan di Google I/O pada tanggal 28 Mei 2015, Marshmallow terutama akan berfokus pada perbaikan inkremental dan penambahan fitur lainnya. Android Nougat 7.0, 7.1, 7.1.1, 7.1.2 (Android 7) 
adalah pengganti dari Android Marshmallow, dan merupakan versi Android kedua terbaru yang telah dirilis. Versi ini diumumkan pada tanggal 1 Juli 2016, dan diluncurkan pada 23 Agustus 2016.

\subsection{Unified Modeling Language UML}

UML

(Unified

Modeling

Language) adalah bahasa pemodelan standar untuk membangun sistem atau perangkat lunak. UML ini merupakan bahasa visual untuk pemodelan bahasa mengarahkan semua komponen dengan diagram berbasis pada object oriented. UML adalah himpunan struktur dan teknik untuk pemodelan desain program berorientasi objek (OOP) serta aplikasinya sebagai salah satu alat atau model merancang pengembangan sistem perangkat lunak berbasis object oriented, menyederhanakan bentuk yang komplek sehingga mudah dipahami dan dipelajari dalam pemodelan sistem.

Skema database yang digunakan, dan komponen-komponen yang diperlukan dalam sistem software. UML bisa digunakan untuk menerangkan bagaimana membuat dan membentuk model-model, tetapi dikatakan yang seharusnya dibuat dengan meru[akan salah satu proses penjabaran pengembangan software.

\section{Use Case Diagram}

Diagram ini menggambarkan apa saja yang akan digunakan dalam sebuah sistem dari pandangan pengamatan luar yang menjadi permasalahan.

\section{Sequence Diagram}

Diagram sequence menggambarkan kelakuan objek pada use case dengan deskripsi waktu hidup objek dan dikirimkan terima antar objek.

\section{Class Diagram}

Diagram kelas merupakan gambaran struktur sistem dari segi pendefinisian kelas-kelas yang akan dibuat untuk membangun sistem, kelas yang memiliki atribut dan metode atau operasi.

\section{Activity Diagram}

Activity diagram mwnggambarkan work flow atau aktifitas sebuah sistem atau proses. Yang diperhatikan disini adalah bahwa diagram menggambarkan aktifitas sistem bukan apa uang dilakukan actor, jadi aktifitas yang dapat dilakukan oleh sistem.

\subsection{FINTECH}

Fintech lebih berpusat denga inovasi jasa keuangan dengan sentuhan teknologi modern. Jenis pun berbagai macam dari pengelolaan asset, e-money, payment gateway, saham, insurance, $\mathrm{P} 2 \mathrm{P}$ Lending, asuransi dan berbagai macam lainnya. Banyak pula perkembangan startup yang ada, dari individu atau institusi melirik startup dengan investasi, dapat menyasar segment perusahaan B2B maupun ritel $\mathrm{B} 2 \mathrm{C}$.

Definisi Fintech (financial technology) dari berbagai sumber adalah sebagai berikut:

Fintech weekly "fintech adalah satusatunya basis bisnis untuk menggunakan layanan keuangan spide profide perusahaan teknologi keuangan pada umumnya startup didirikan dengan tujuan membalikkan sistem keuangan incumbent dan perusahaan yang mengandalkan perangkat lunak."

Value-system "fintech adalah teknologi yang melayani klien lembaga keuangan, tidak hanya mencangkup kantor di belakang dan tengah tapi juga front office yang tertutup yang selama ini telah 
digerakkan manusia."

Kantox-FX "fintech adalah kontraksi "keuangan"dan "teknologi" mengacu perusahaan yang menyediakan layanan keuangan melalui keterlibatan teknologi."

\subsection{Extreme programing.}

Extreme programming adalah suatu model yang termasuk pendekatan agile yang diperkenalkan oleh Kent Back dan Ward Cunningham maret 1994. Tujuan XP adalah menurunkan biaya dalam pengembangan sistem traditional sehingga kebutuhan sistem ditentukan tahapan awal pengembangan proyek dan bersifat fixed. Menurut penjelasannya adalah sebagai berikut "metode pengembangan software yang cepat, efisien, beresiko rendah, fleksibel, terprediksi, scientific, dan menyenangkan". Extreme programing muncul dengan sebuah disiplin baru pengembangan software secara "agile", nilai dasar yang terkandung didalam (XP) adalah komunikasi (communication), kesederhanaan (simplicity), Umpan Balik (Feedback), keberanian (courage) dan menghormati (Respect). Proses dalam extreme programming menurut Pressman (2010) yaitu :

1. Planning. Tahap planning dengan membuat user stories menggambarkan output, fitur, fungsi, ari software-software yang akan dibuat.

2. Design. Design di XP mengikuti prinsip keep is simple.design yang sulit akan menggunakan spike solution dimana pembuatan langsung ketujuannya.

3. Coding. Proses coding diawali dengan membangun serangkaian unit test, pengembangan akan berfokus pada mengimplementasikan.

4. Testing. Dilakukan pengujian kode pada unit test dalam extreme programming, diperkenalkan customer test test ini di lakukan oleh customer yang terfokus pada fitur, dan fungsi sistem secara keseluruhan.

\section{METODOLOGI PENELITIAN}

kemudahan dalam layanan transaksi saat ini berkembang dengan pelayanan penyedia jasa keuangan menyediakan kemudahan untuk layanan keuangan yang perusahaan miliki, dengan efisiensi dan keefektifitasan antara administrator dan klien jasa keuangan dalam sebuah sistem informasi koperasi diharapkan menjadi pengelolaan bentuk sebuah transaksi dan data informasi koperasi yang diberikan mengutamakan sisi kedua belah pihak untuk memudahkan segala transaksi dalam koperasi menjadi sebuah informasi yang valid, akurat, dan efektif untuk mencapai tujuan dalam peningkatan pelayanan jasa keuangan di bidang usahanya.

\subsection{Analisa Sistem Berjalan}

Proses penyampaian dan pencarian seperti berikut :

1. Administrator menanyakan keanggotaan kepada Calon anggota baru

2. Calon anggota koperasi memberikan fotokopi prasyarat dan ketentuan yang tersedia lalu Administrator.

3. Setelah anggota menyerahkan prasyarat dan ketentuan yang berlaku selanjutnya anggota memilih bentuk tabungan simpanan, simpanan berjangka, paket harian(non anggota koppas), SIKOCIR (simpanan koperasi ciracas) atau dan lain lain.

4. Setelah memilih bentuk tabungan anggota kemudian Administrator menginput data dalam komputer lalu diberikan buku tabungan.

5. Selesai data administrasi lengkap administrator memastikan tersimpan 
sebagai data arsip.

6. Lalu administrator melaporkan data anggota baru dalam data anggota baru.
Untuk mengetahui aliran dokumen pendaftaran koperasi pasar ciracas maka akan digambarkan Flow Of Dokumen seperti dibawah ini:

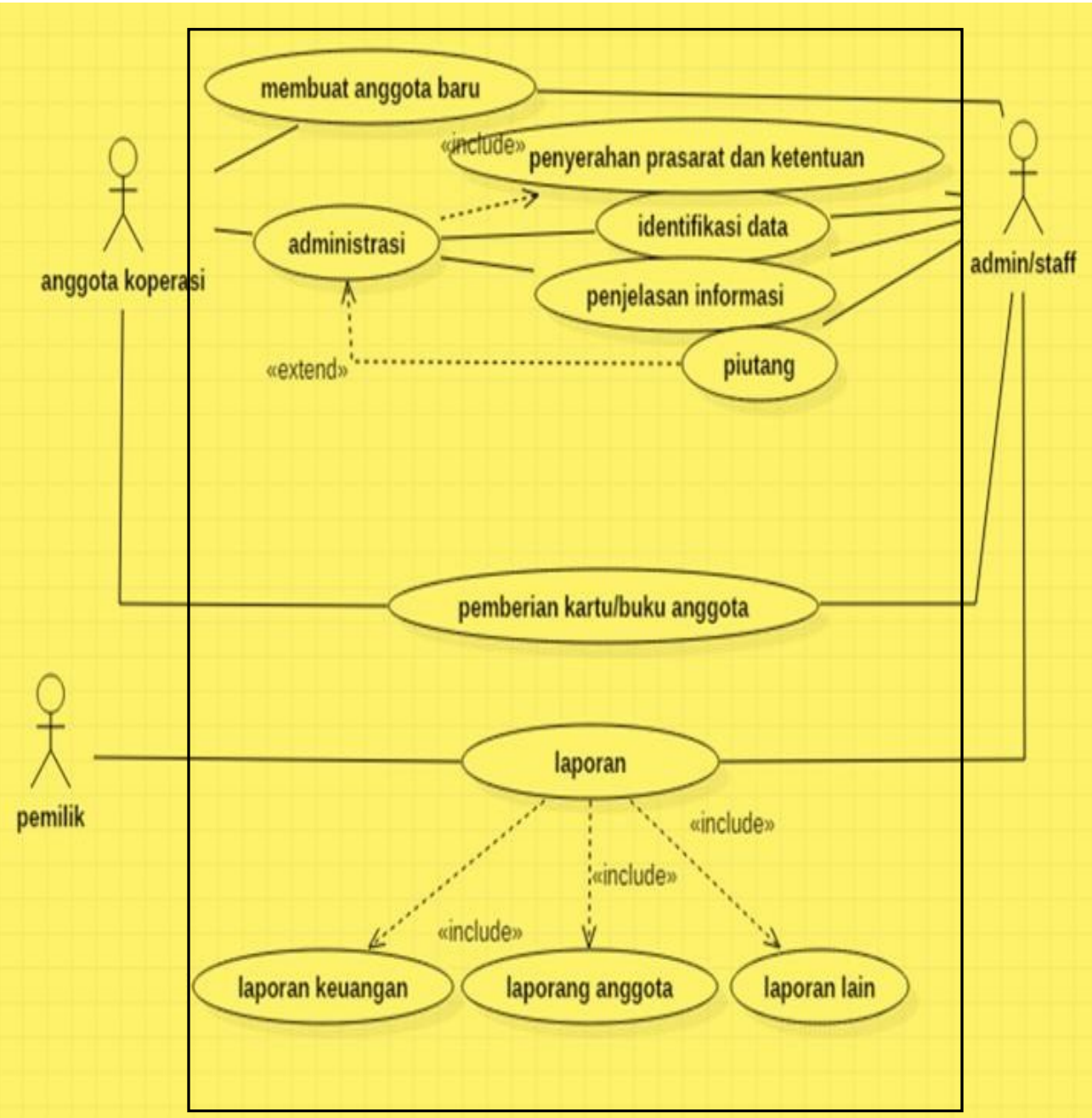

Gambar 3.4 Use Case Diagram pelayanan koperasi Pasar Ciracas

\subsubsection{Identifikasi Usecase Pelayanan} Koperasi pasar Ciracas

Sebelum menjadi anggota koperasi pasar ciracas harus datang langsung untuk pengisian anggota baru dan menyerahkan syarat dan ketentuan yang berlaku serta akan diberi penjelasan tentang koperasi Pasar Ciracas proses pendaftaran formulir selesai.

Administrator akan mengecek pendaftaran tersebut dengan memberikan fotokopi KTP (Kartu Tanda Penduduk) 1 buah yang aktif, dan persyaratan penyetoran pertama dan memberikan pilihan untuk bentuk simpanan yang ada dan yang akan di ikuti oleh anggota.

Bila sudah melengkapi persyaratan dan ketentuan yang berlaku anggota akan diberikan buku tabungan anggota jika telah saling menyetujui admin akan mennjelaskan beberapa program yang sudah berjalan dan jenis simpan pinjam dengan prasyarat yang harus ditaati bagi setiap anggota Sikocir 
maupun Non anggota. Setelah selesai administrator menyimpan data anggota guna mengarsipkan untuk keperluan sewaktu waktu.

Sesudah semua selesai admin melaporkan dalam buku laporan kepada pemilik untuk pendaftaran dengan syarat dan ketentuan yang berlaku dalam unit Koperasi Pasar Ciracas KOPPAS CIRACAS.

3.2 Permasalahan dan Alternatif Masalah

\subsubsection{Permasalahan}

Permasalahan yang timbul dari sistem dokumentasi kertas yang diterapkan di koperasi pasar ciracas (KOPPAS CIRACAS) banyaknya sistem manual menggunakan kertas akan meninggalkan tumpukkan kertas menimbulkan file file data tertumpuk sehingga menimbulkan membutuhkan waktu dalam merinci setiap kertas dan mengidentifikasi, file yang akan dicari akan menjadi sulit kebutuhan suatu waktu dibutuhkan kembali akan membutuhkan waktu dan anggota dapat menginformasikan data ulang atau meminta data langsung ke kantor untuk mengkonfirmasikan.

\subsubsection{Data Pendaftaran}

Bagi pendaftaran Administrator adalah untuk mengecek data anggota dengan pendaftaran setiap anggota apakah benar atau tidak jika berkas hilang maka akam menyulitkan pencarian data anggota yang terdaftar dalam koperasi pasar ciracas dan anggota akan dimintai data kembali.

\subsubsection{Pengajuan Pinjaman}

Formulir pengajuan hutang adalah form yang diisi oleh anggota untuk mengisi data diri secara lengkap dengan syarat dan ketentuan yang telah dijelaskan dalam pengajuan pinjaman dengan melihat sisa pinjaman maupun pinjaman yang di ajukan admin akan mengecek dengan data yang ada dan segera akan diproses oleh koperasi baik akan diterima atau ditolak pengajuan pinjaman tersebut.

\subsubsection{Kartu pinjaman KOPPAS CIRACAS \\ Kartu pinjaman KOPPAS} CIRACAS digunakan Admin dan anggota untuk bukti penerimaan pembayaran kedua belah pihak barapa angsuran yang berjalan, saldo yang ada, dan pertanggung jawaban dari laporan petugas untuk hutang yang berjalan.

\subsubsection{Sistem Koperasi Pasar ciracas yang Berjalan Manual \\ setiap anggota baru yang ingin} mendaftar harus datang langsung untuk mengajukan pendaftaran pada admin kemudian admin akan menjelaskan dan meminta kepada calon untuk menyerahkan data diri karna blm tersedianya form pendaftaran sehingga langsung dicatat dalam sistem, akan dijelaskan beberapa produk yang ada dalam koperasi dan prasyarat ketentuan yang sudah dimiliki koperasi lalu dengan masih menggunkannya kertas sebagai form dan file anggota maka akan bannyaknya penumpukan data untuk menyimpan data data anggota.

\subsection{Sistem Berjalan}

\subsubsection{Sistem Berjalan Pendaftaran}

Prosedur keanggotaan Koperasi Pasar Ciracas (KOPPAS CIRACAS) sebagai berikut:

1. Calon anggota datang langsung ke koperasi untuk melakukan pendaftaran anggota.

2. Bagian admin meminta foto kopi ktp untuk non anggota maupun fc mktp dan surat kepemilikan kios pasar ciracas untuk anggota koppas ciracas.

3. Calon anggota akan dijelaskan 
bentuk tabungan apa yang akan dipilih oleh administrasi.

4. Jika sudah admin akan mengecek kembali persyaratan yang ada berlaku agar calon anggota menjadi anggota.
5. anggota dipersilahkan menunggu sebentar kemudian admin akan menginput dalam file dan disimpan kemudian memberikan buku tabungan dan nomor anggota.

Tabel 3.4 Flowmap Pendaftaran Anggota Koperasi Pasar Ciracas

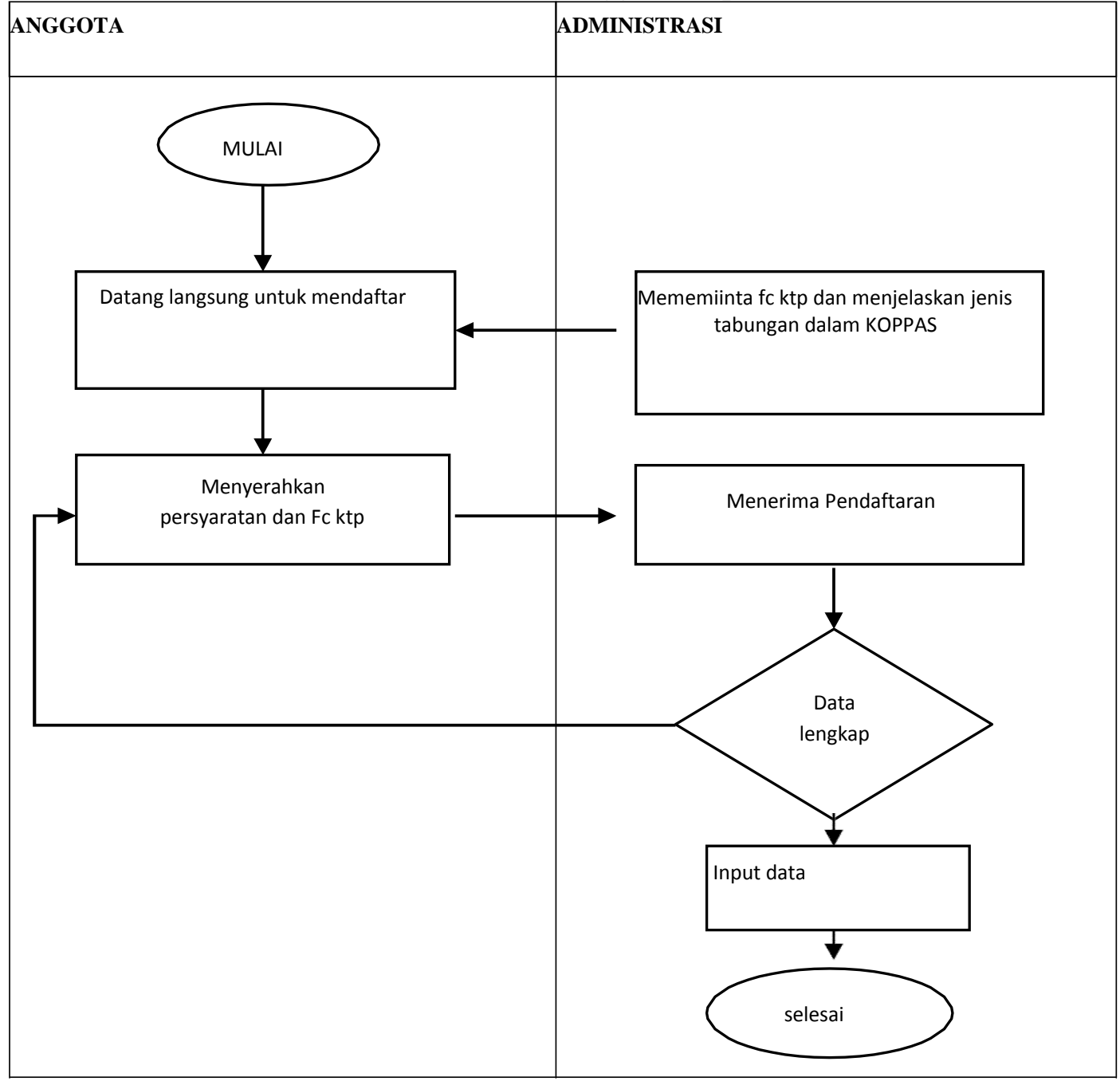

\subsubsection{Sistem Berjalan Simpan Pinjam}

Prosedur simpan pinjam dalam kopersi pasar ciracas "KOPPAS Ciracas" adalah sebagai berikut :

1. Anggota koperasi membayar simpanan pokok dan wajib secara langsung saat pendaftaran mengikuti koperasi secara rutin.

2. Peminjaman yang akan diajukan anggota harus mengisi pengajuan hutang terlebih dahulu pada bagian admin.

3. Admin memberikan form pengajuan hutang kepada anggota

4. Angggota dipersilahkan mengisi form dan kembalikan form tersebut beserta persyaratan yang ditetapkan koperasi.

5. Bagian admin akan mengecek kevalidan data-data anggota 
kemudian jika tidak lengkap persyaratan akan dikembalikan ke anggota untuk di lengkapi

6. Jika lengkap akan diserhkan kebendahara untuk diproses.

7. Proses selanjutnya anggota akan di mengisi form pengakuan hutang sebagai pertanggung jawaban atas hutang yang diajukan kepada koperasi.
8. Jika lengkap maka penandatanganan kedua belah pihak dan diserahkan ke bagian keuangan agar dana dicairkan. Bagian keuangan mencatat input data ke file pinjaman dan diarsipkan.

9. Bagian keuangan akan memberikan jumlah peminjaman sesuai nominal yang diajukan dan disepakati oleh anggota dengan koperasi

Table 3.5 flowmap sistem simpan pinjam pada koperasi pasar ciracas

"KOPPAS Ciracas"

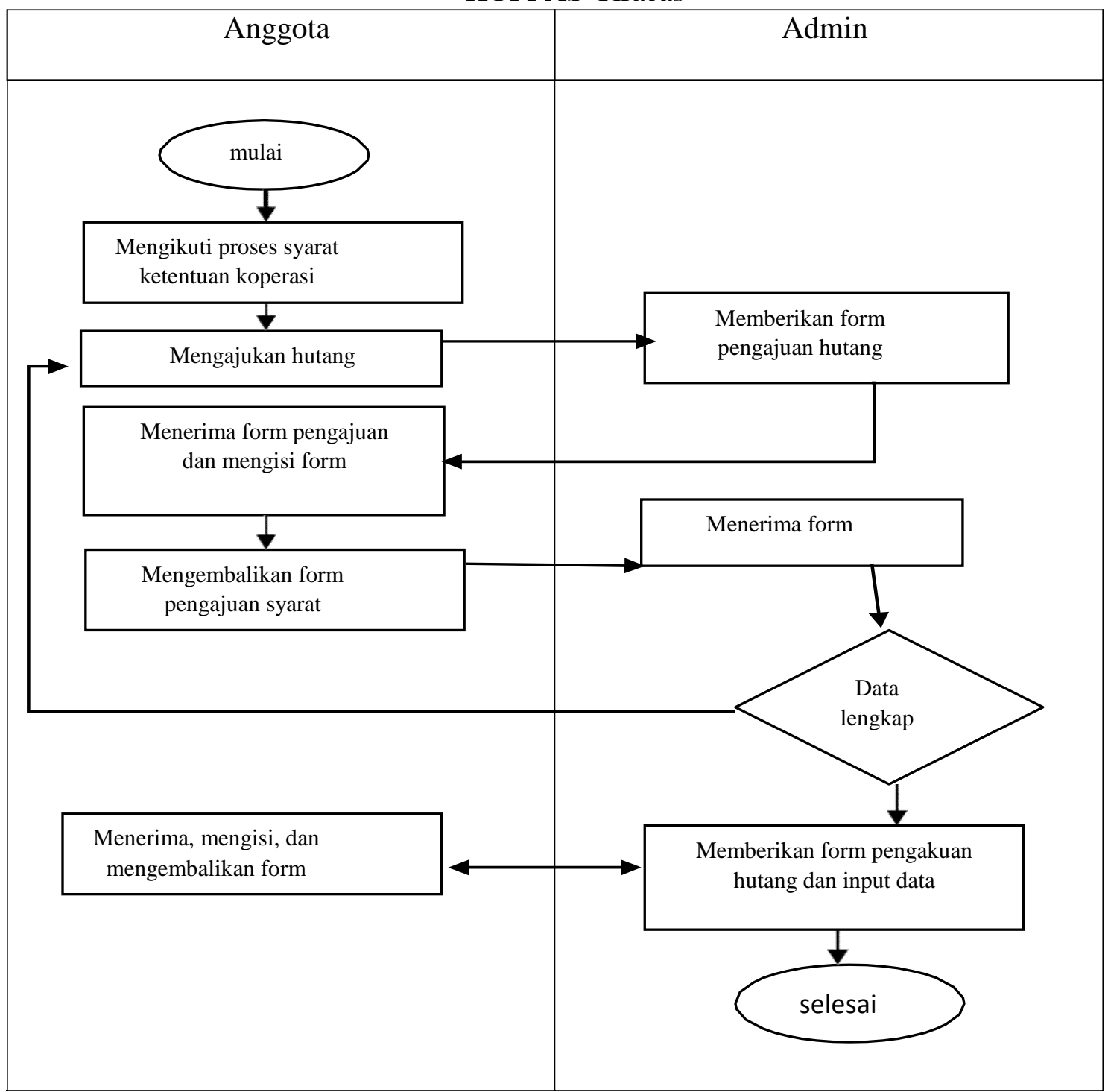




\subsubsection{Sistem Berjalan Cek Saldo}

Prosedur cek saldo koperasi pasar ciracas "KOPPAS CIRACAS" sebagai berikut ;

1. Anggota datang langsung ke administrasi untuk meminta data ceksaldo agar dicetak atau diberitahu berapa nominal yang sudah diterima. Atau anggota akan menunggu tiap akhir bulan admin akan mengecek dengan meminta buku pada setiap anggota untuk memvalidasi antara sistem dengan data tercatat.

2. admin akan meminta kartu dan buku anggota untuk mensingkronkan data data yang telah terdata. Apabila sudah di kerjakan maka buku tabungan anggota akan diserahkan kembali ke setiap anggota.

3. Anggota menerima buku tabungan dan kartu setoran untuk melihat saldo yang telah masuk maupun keluaran piutang atas kredit yang dimiliki.

Table 3.6 flowmap cek saldo koperasi pasar ciracas "KOPPAS Ciracas"

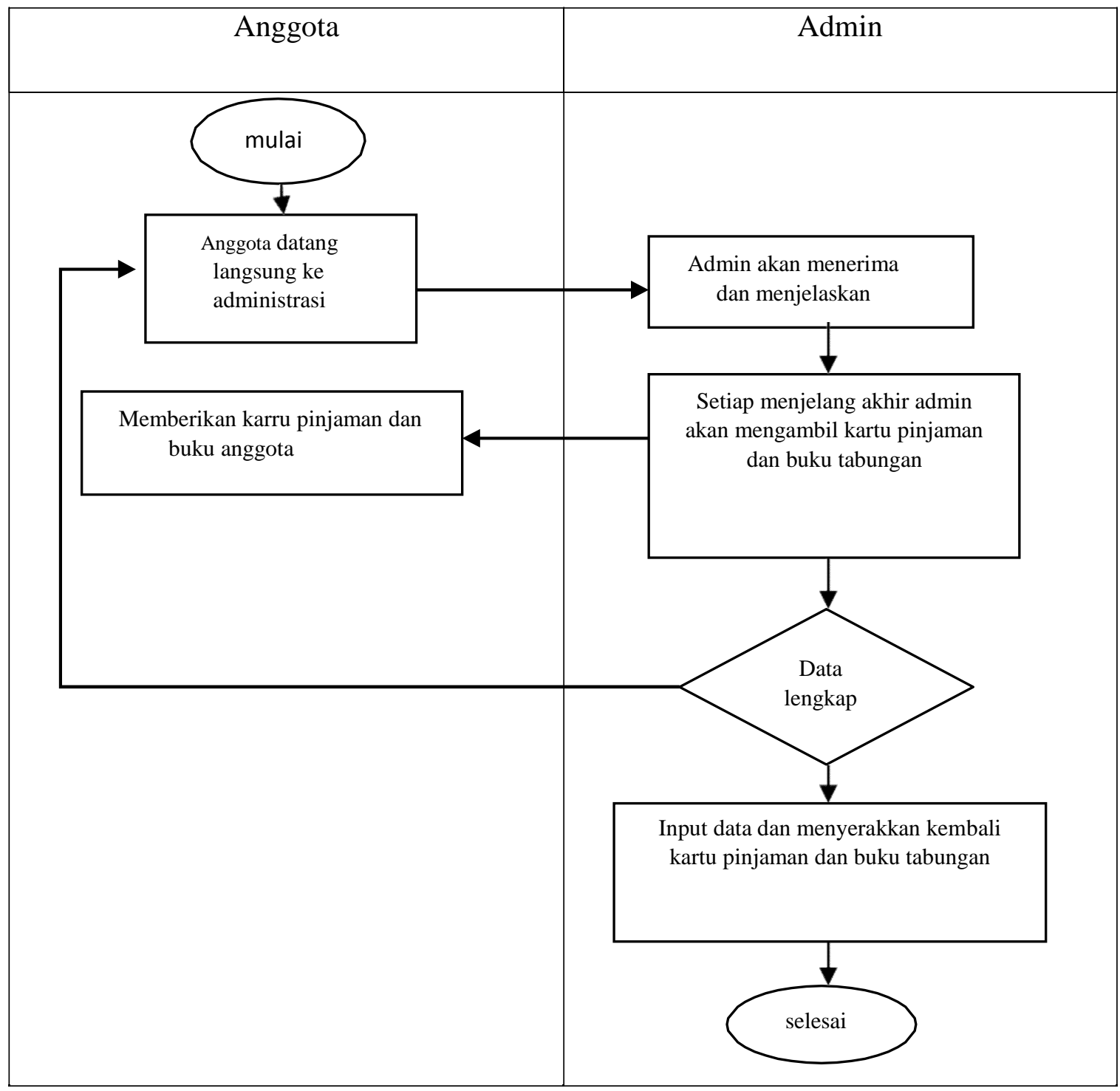


Tabel 3.7 flowmap sistem berjalan pada koperasi pasar ciracas "KOPPAS Ciracas"

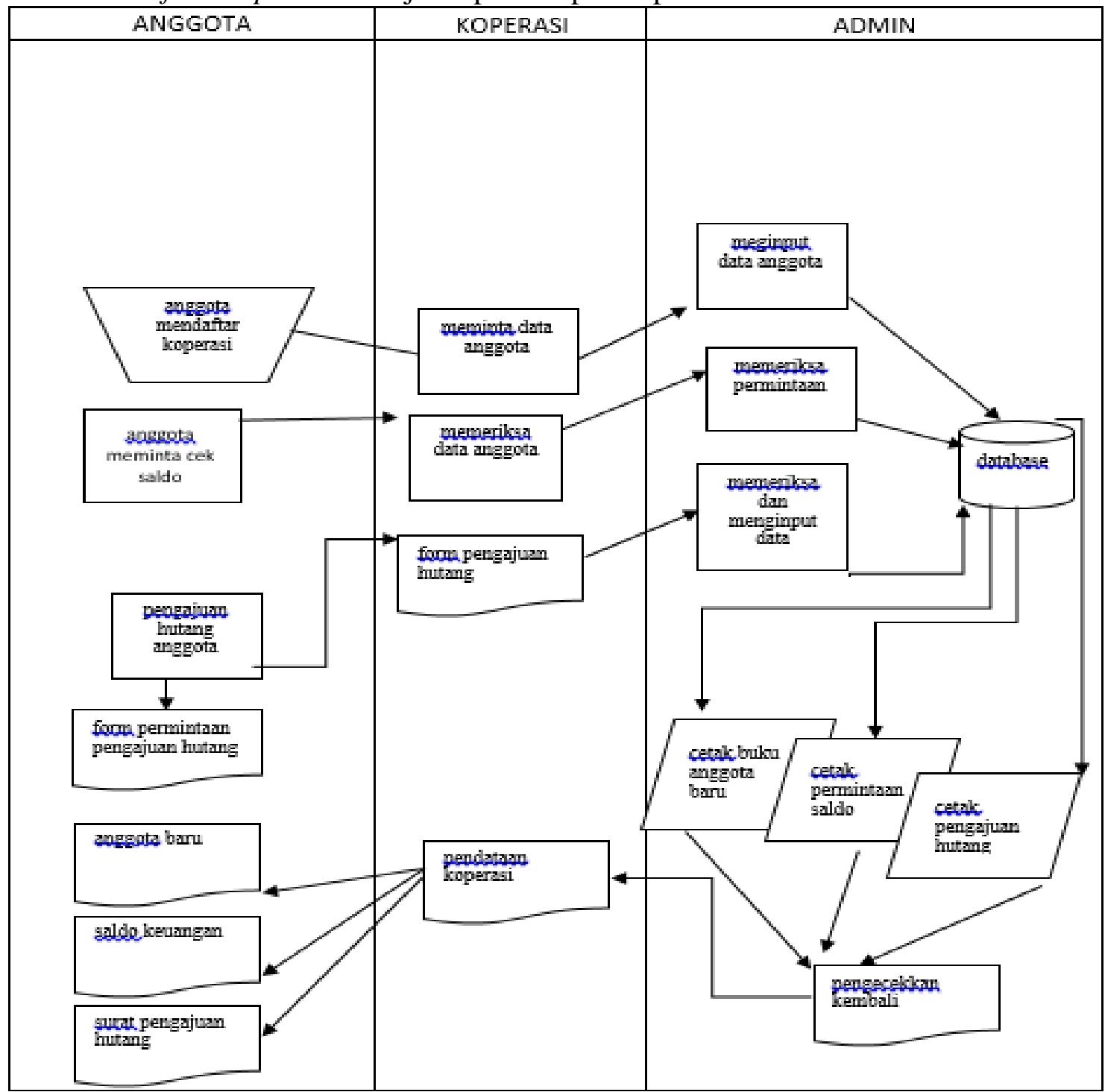

\subsubsection{Analisis usulan sistem}

Dari permasalahan diatas maka peneliti memberikan alternatif dengan menggunakan pemecahan masalah dengan mempermudah staff melakukan proses pengolahan data dan menyampaikan informasi yang manual kepada anggota menjadi aplikasi berbasis android yang bisa diakses setiap anggota untuk bertujuan mendapatkan laporan saldo keuangan anggota dan angsuran pinjaman piutang yang setiap anggota miliki, juga dapat mengakses rekapitulasi keuangan anggota dan pengajuan hutang anggota melalui smartphone anggota.
Berikut sistem yang dapat pada menu yang diusulkan untuk Koperasi pasar Ciracas ( KOPPAS CIRACAS ). Daerah ciracas Jakarta timur :

\section{Menu KOPPAS CIRACAS}

Pada menu ini pengguna dapat memilih transakasi yang diinginkan terdiri dari akun anggota, tampilan saldo tabungan dan saldo piutang yang pengguna punya, pengajuan pinjaman.

2. Menu profil

Pada menu ini adalah akun anggota yang dapat di ubah sesuai dengan 
profil anggota.

3. Menu rekapitulasi

Pada menu ini anggota dapat melihat rekapitulasi keuangan yang dimiliki dalam koperasi per transaksi.

4. Menu cek hutang

Menu ini anggota dapat melihat pertransaksi pembayaran cicilan hutang yang anggota miliki.

5. Menu Pengajuan

Pada menu ini anggota dapat mengajukan pinjaman sebatas pengajuan pinjaman saja.

6. Menu keluar Menampilkan keluar

\section{PERANCANGAN SISTEM DAN IMPLEMENTASI \\ 4.1 Perancangan Sistem}

Pada bagian ini dijelaskan mengenai sistem informasi koperasi sebagai reminder pada koperasi pasar ciracas berbasis android perancangan menggunakan notasi UML.

\subsubsection{Use Case Diagram}

Komponen use case diagram terdiri dari aktor, usecase, dan relasi. Aktor adalah pemain, usecase adalah apa yang dilakukan dengan relasi sebagai petunjuknya. Pada gambar 4.1 menggambarkan aktifitas yang dapat pengguna digunakan dalam membuka aplikasi, login, menu profil, menu saldo, menu headline, menu pengajuan hutang, menu cek hutang, rekapitulasi, menu keluar:

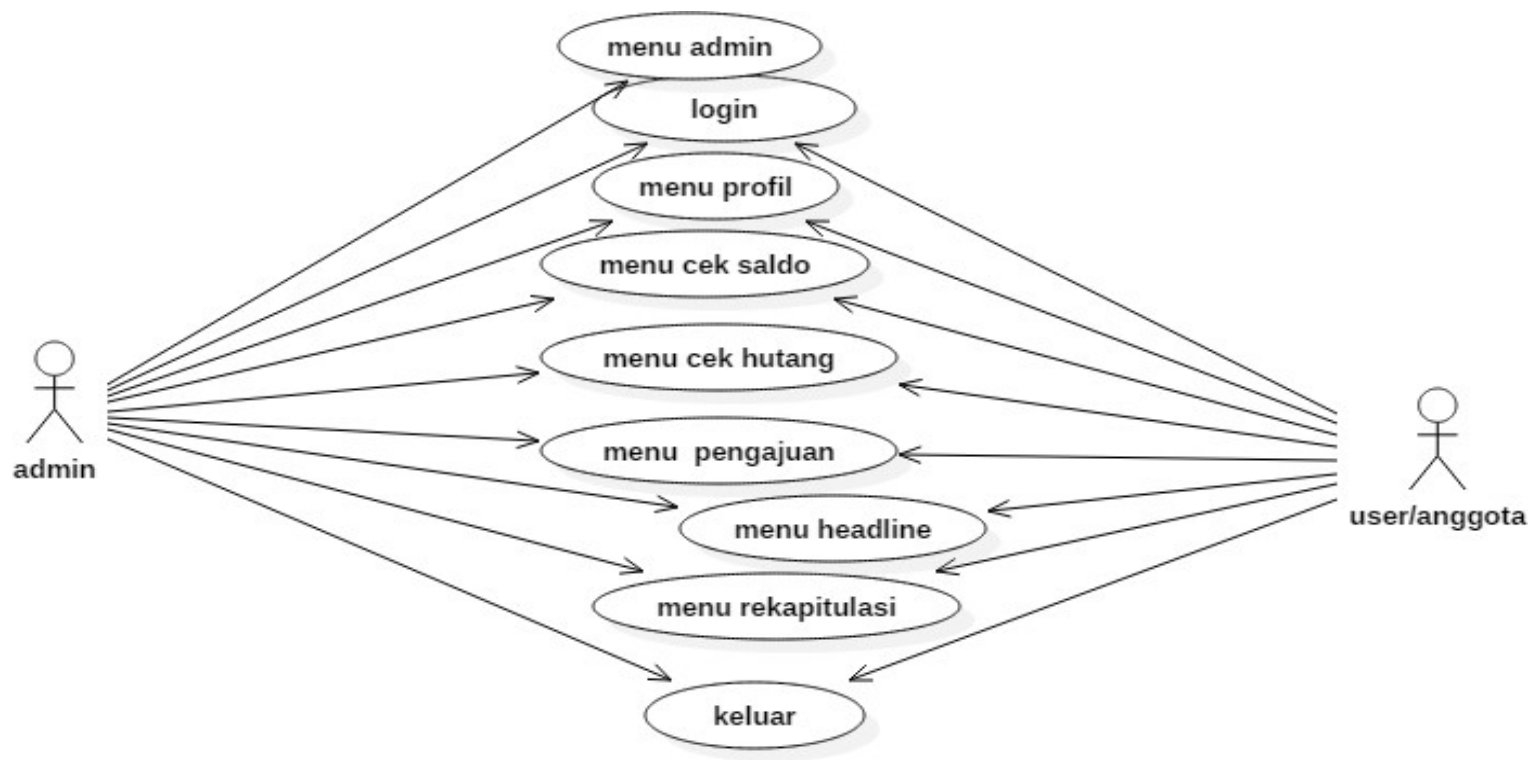

Gambar 4.1 use case diagram Sistem Usulan

\subsection{Diagram Activity}

Activity Diagram dalam membuat aplikasi ini memiliki tahapan-tahapan yang perlu dilakukan untuk menjalankan dengan memulai dari pengguna membuka aplikasi lalu sistem menampilkan aplikasi koperasi dilanjutkan pengguna memilih menu yang diinginkan untuk digunakan.

\subsubsection{Diagram Activity Aplikasi Koperasi Ciracas (KOPPAS CIRACAS)}

Gambar dibawah ini merupakan desain diagram activity menu Koperasi Pasar Ciracas: 


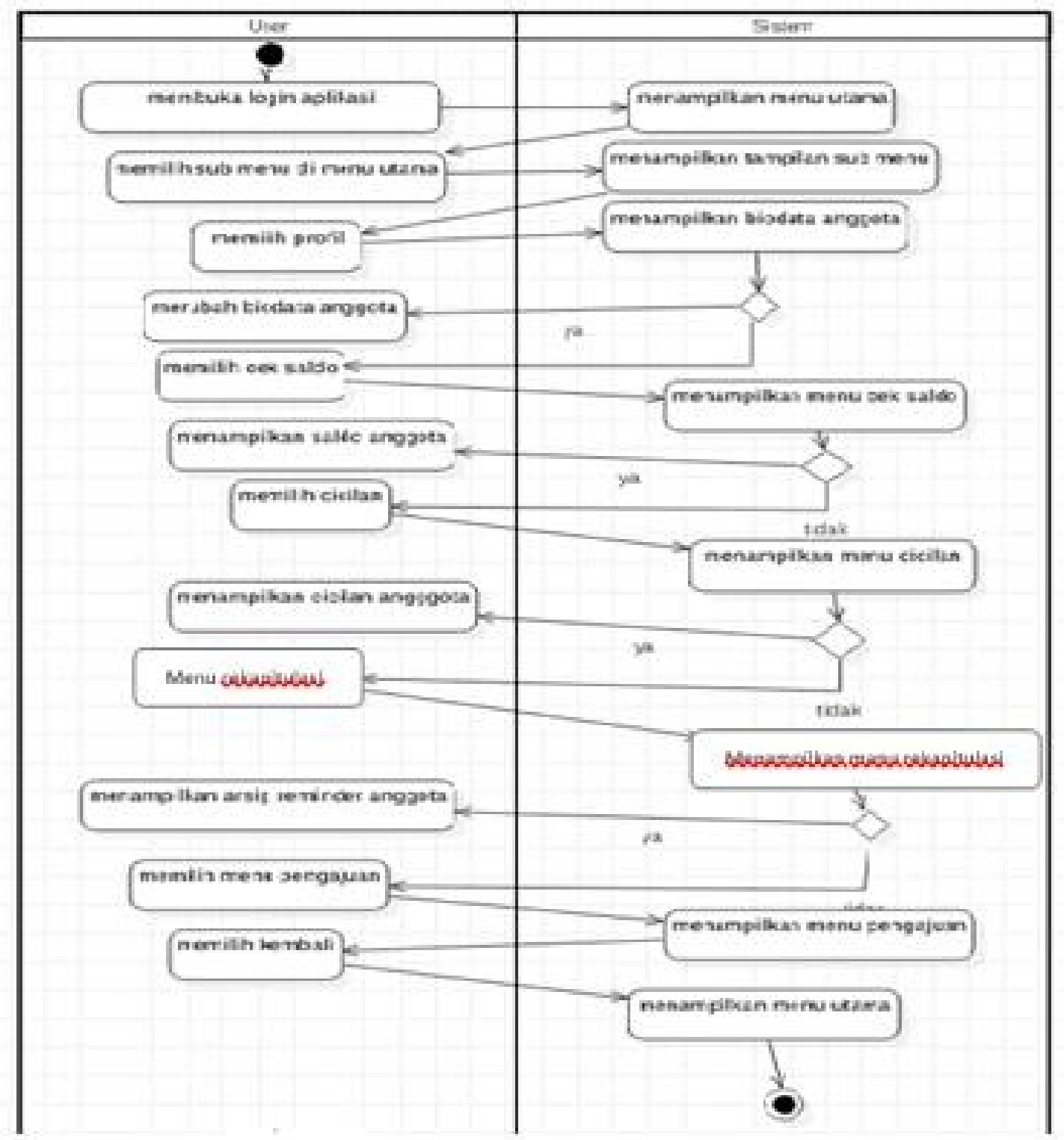

Gambar 4.2 Activity diagram Sistem aplikasi koperas

Pada gambar diatas menjelaskan tahapan yang ada perlu dijalankan tahapan yang dimulai dengan pengguna login ke dalam aplikasi maka sistem membuka tampilan menu utama dilanjutkan dengan memilih menu profil, sistem menampilkan menu biodata dari data anggota tersebut sehingga anggota dapat mengedit data anggota tersebut jika tidak dapat memilih menu cek saldo untuk mengecek saldo tabungan dari data keuangan setiap anggota jika sudah dapat kembali dan pengguna dapat memilih cicilan untuk mengetahui cicilan utang yang anggota miliki dalam setiap saat, jika tidak dapat kembali memilih menu rekapitulasi untuk reminder anggota total membayar hutang, penarikan, dan saldo menabung dan juga tunggakan piutang anggota, jika sudah kembali dan memasuki menu pengajuan lalu sistem akan menampilkan menu pengajuan jika tidak memilih kembali dan anggota akan menampilkan menu utama kembali pemberitahuan yang masuk akan ditampilkan di masing masing menu 
aplikasi.

\subsubsection{Diagram Activity Profil}

Berikut adalah desain UML diagram activity menu profil pada menu ini merupakan menampilkan profil biodata anggota, anggota dapat mengubah biodata anggota juga dapat merubah pin anggota:

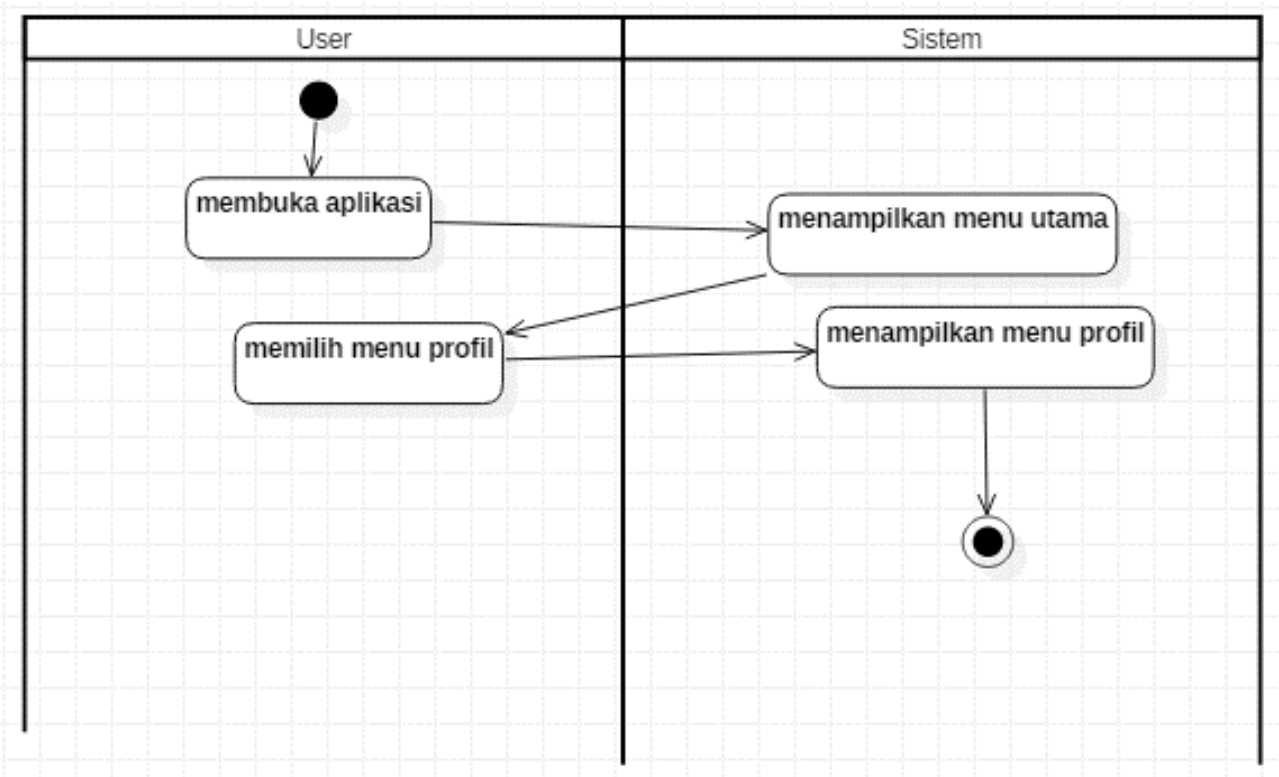

Gambar 4.3 Activity diagram menu profil Penulis (2019)

\subsubsection{Diagram Activity Menu Cek Saldo}

Berikut ini merupakan desain UML activity diagram menu cek saldo:

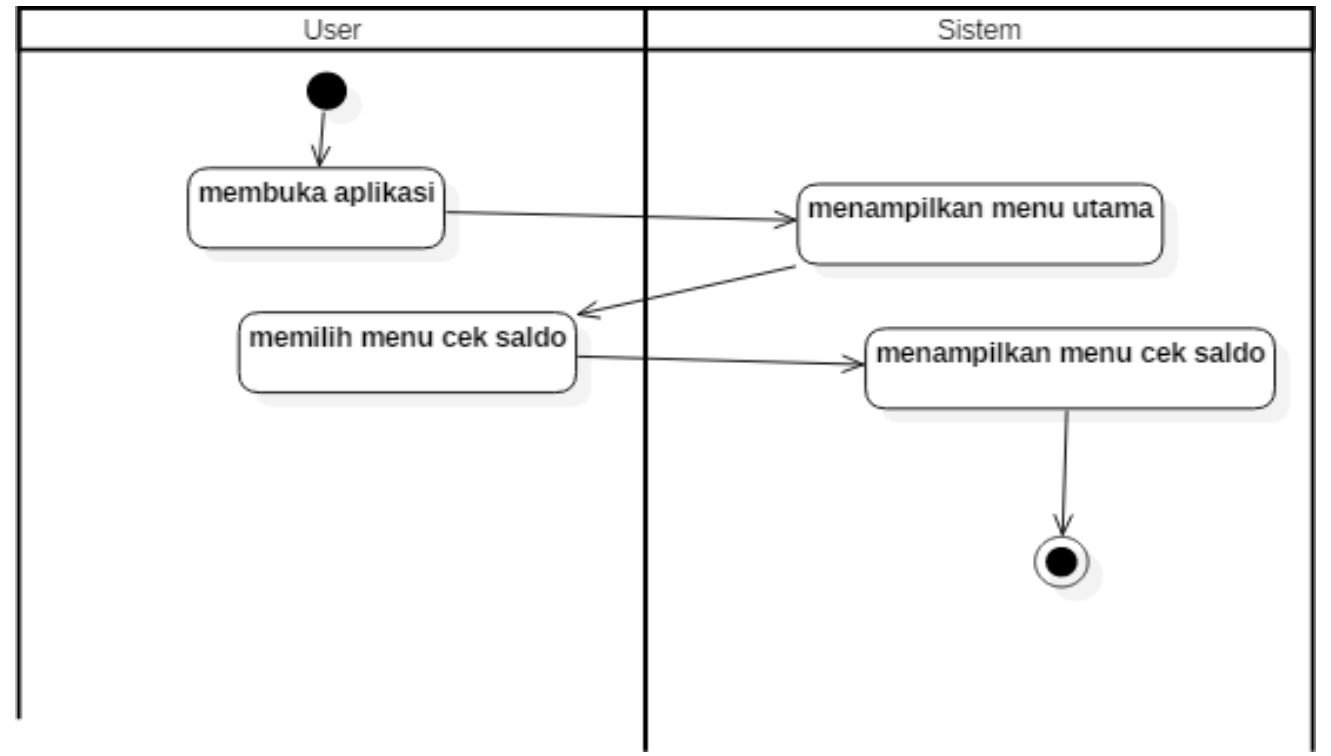

Gambar 4.4 Activity diagram Menu cek saldo Penulis (2019) 
Pada menu cek saldo anggota sebagai user bisa melihat data saldo yang anggota miliki dengan akses pribadi akun setiap anggota berbeda beda sesuai akun anggota yang bersangkutan.

\subsubsection{Diagram Activity Menu Headline \\ Berikut ini merupakan desain} UML activity diagram menu Headline:

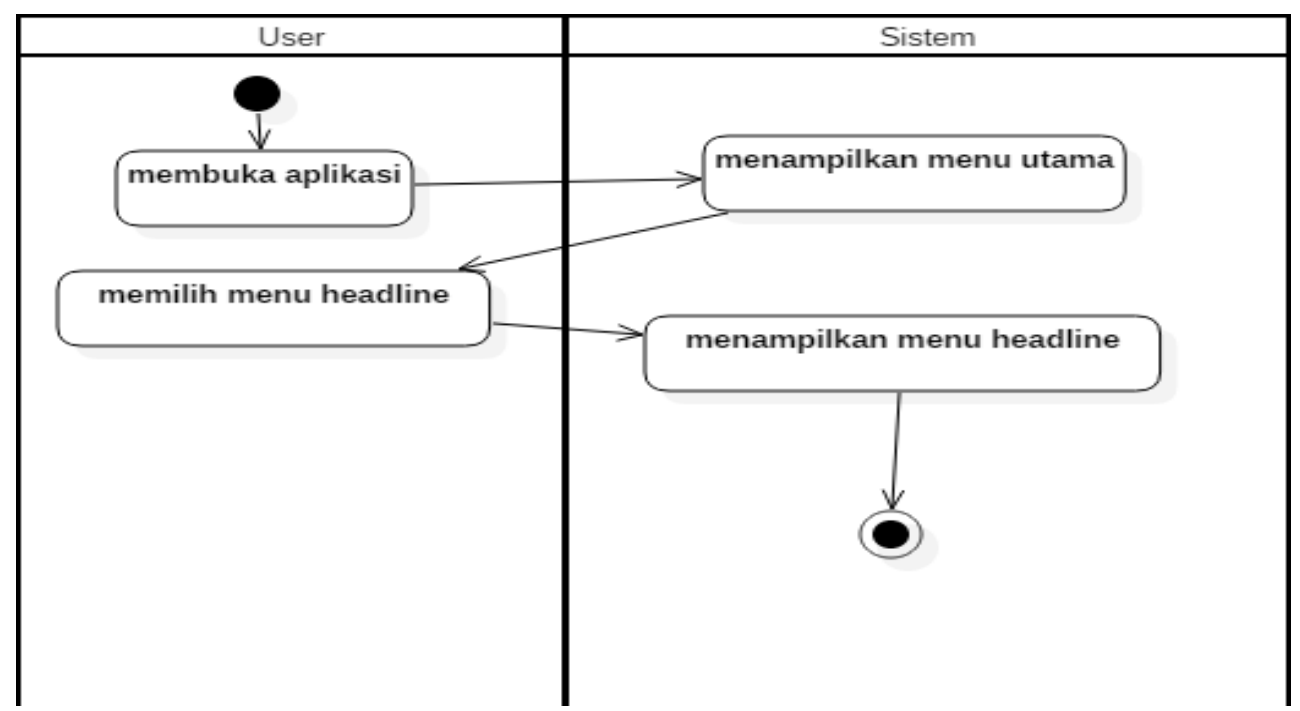

Gambar 4.5 Activity diagram Menu Headline Penulis (2019)

Pada menu headline anggota sebagai user bisa melihat berita update dalam koperasi seperti perkembangan koperasi, laporan keuangan koperasi pertahun yang anggota miliki dengan akses pribadi akun setiap anggota.

\subsubsection{Diagram Activity Menu Cek Hutang}

Pada diagram activity menu cek hutang merupakan menu cek hutang anggota yang telah masuk dalam akun anggota, anggota bisa melihat transaksi pembayaran piutang dalam menu ini, berikut ini merupakan desain UML activity diagram menu cek hutang:

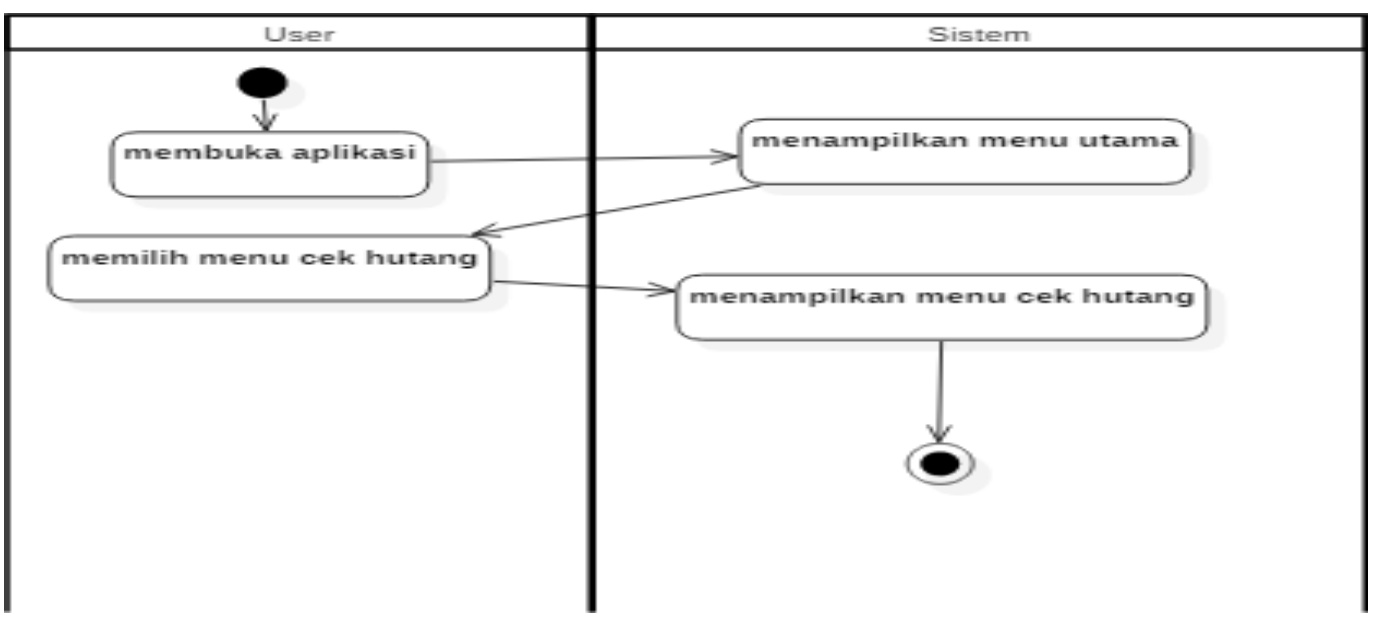

Gambar 4.6 Activity diagram Menu Cek Hutang Penulis (2019) 


\subsubsection{Diagram Activity Rekapitulasi}

Berikut ini merupakan desain UML diagram activity menu rekapitulasi :

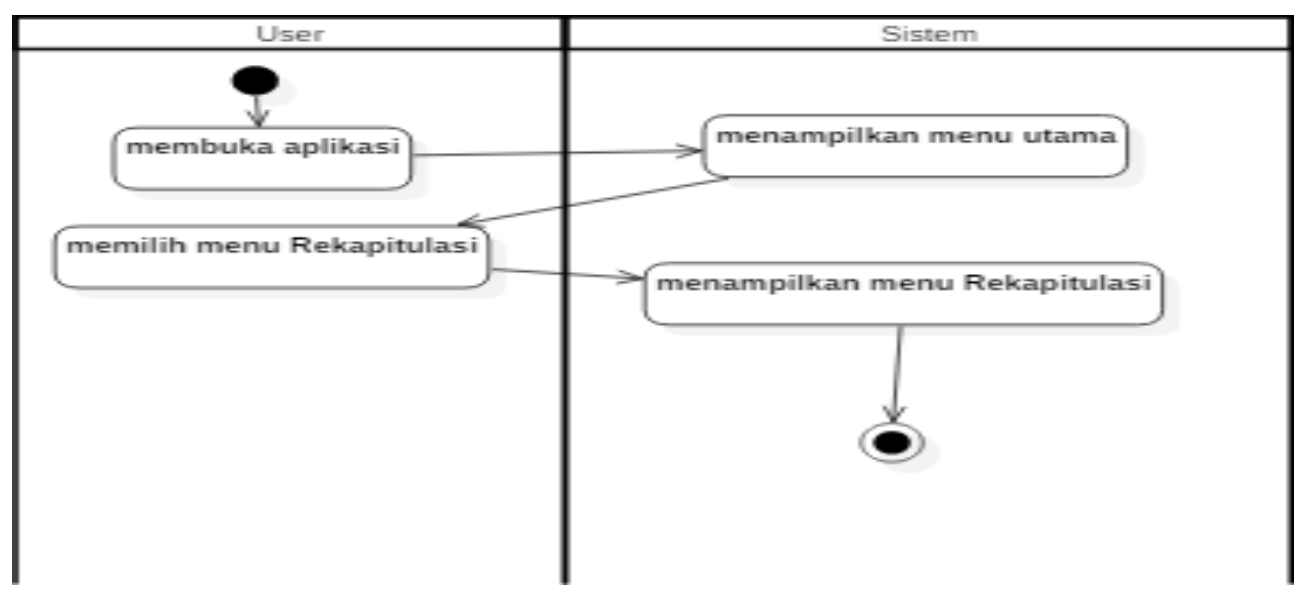

Gambar 4.7 Activity diagram Menu Rekapitulasi Penulis (2019)

Pada menu ini merupakan menu rekapitulasi keuangan dari jumlah total tabungan, total hutang, jumlah total penarikan, akun anggota dalam setiap transaksi.

\subsubsection{Diagram Activity Menu Pengajuan \\ Pada diagram activity menu} pengajuan merupakan menu Pengajuan anggota yang telah masuk dalam akun anggota, anggota bisa mengajuakan hutang pada menu ini, berikut ini merupakan desain UML activity diagram menu pengajuan:

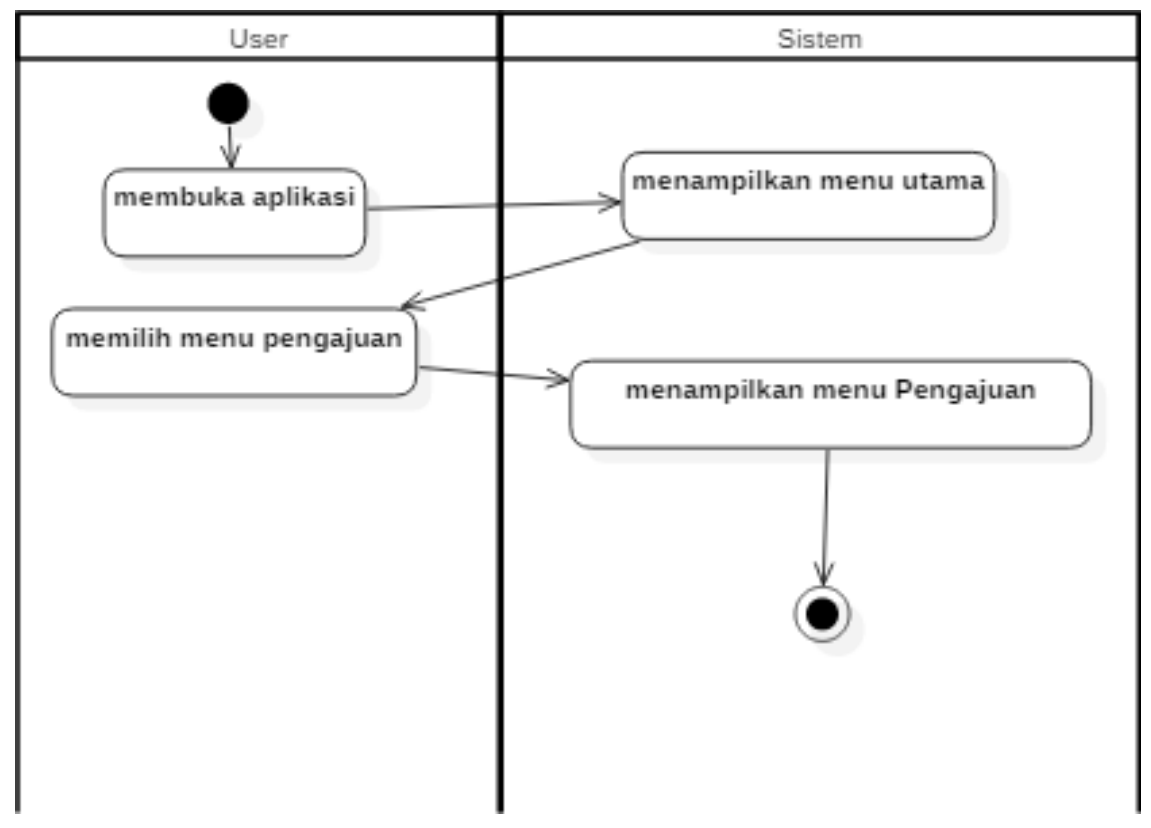

Gambar 4.8 Activity diagram Menu Pengajuan Penulis (2019) 


\subsubsection{Diagram Activity Menu Keluar}

Pada desain UML diagram activity menu keluar berikut menu keluar ini :

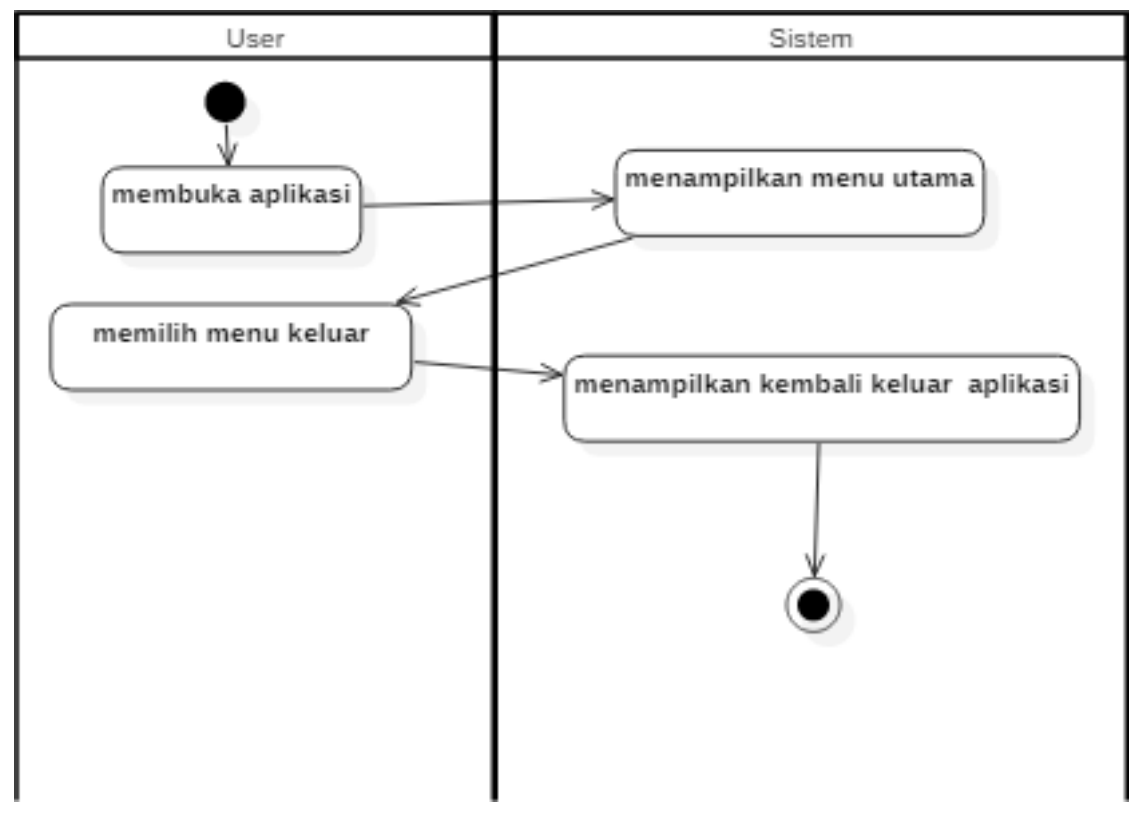

Gambar 4.9 Activity diagram Menu keluar Penulis (2019)

Pada diagram ini menampilkan penjelasan menu keluar, jika pengguna menggunakan aplikasi dan ingin keluar dari aplikasi.

\subsection{Diagram Sequence}

Sequence diagram adalah suatu diagram yang memperlihatkan atau menampilkan interaksi-interaksi antar objek di dalam sistem yang disusun pada sebuah urutan atau rangkaian waktu. Interaksi antar objek tersebut termasuk pengguna, display,dan sebagianya merupakan sebuah pesan.

\subsubsection{Diagram Sequence Aplikasi Koperasi}

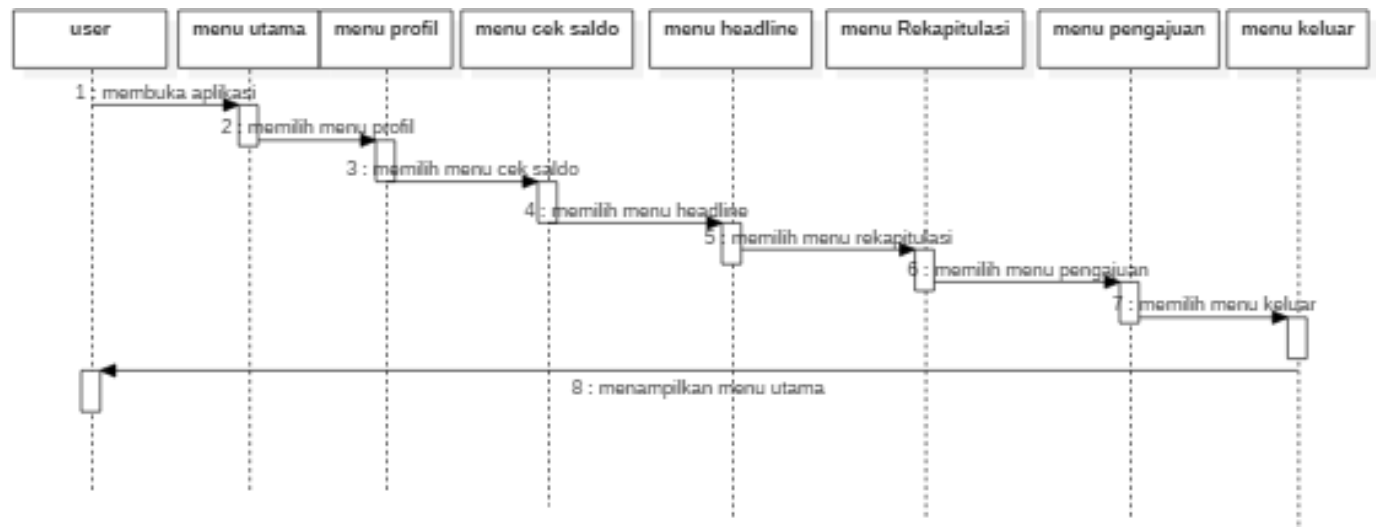

Gambar 4.10 Sequence diagram aplikasi koperasi Penulis (2019) 
Pada diagram ini menu aplikasi koperasi, sesudah user mengakses aplikasi maka sistem akan menampilkan menu utama jika user memilih salah satu dari menu maka sistem akan menampilkan menu tersebut untuk di tampilkan.

\subsubsection{Diagram Sequence Menu Profil}

Bagian diagram berikut ini merupakan diagram sequence dari menu profil, ketika sesudah user masuk aplikasi maka sistem akan menampilkan menu utama, user akan memilih menu profil sistem akan menampilkan menu tersebut ditampilkan sebagai berikut:

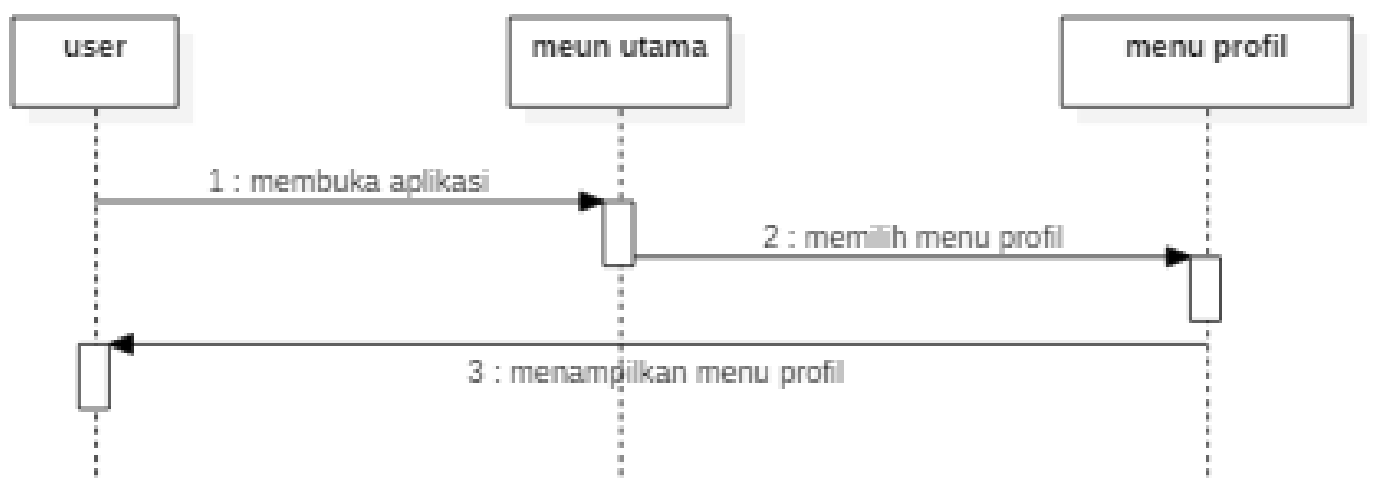

Gambar 4.11 Sequence diagram menu Profil Penulis (2019)

\subsubsection{Diagram Sequence Menu Cek Saldo}

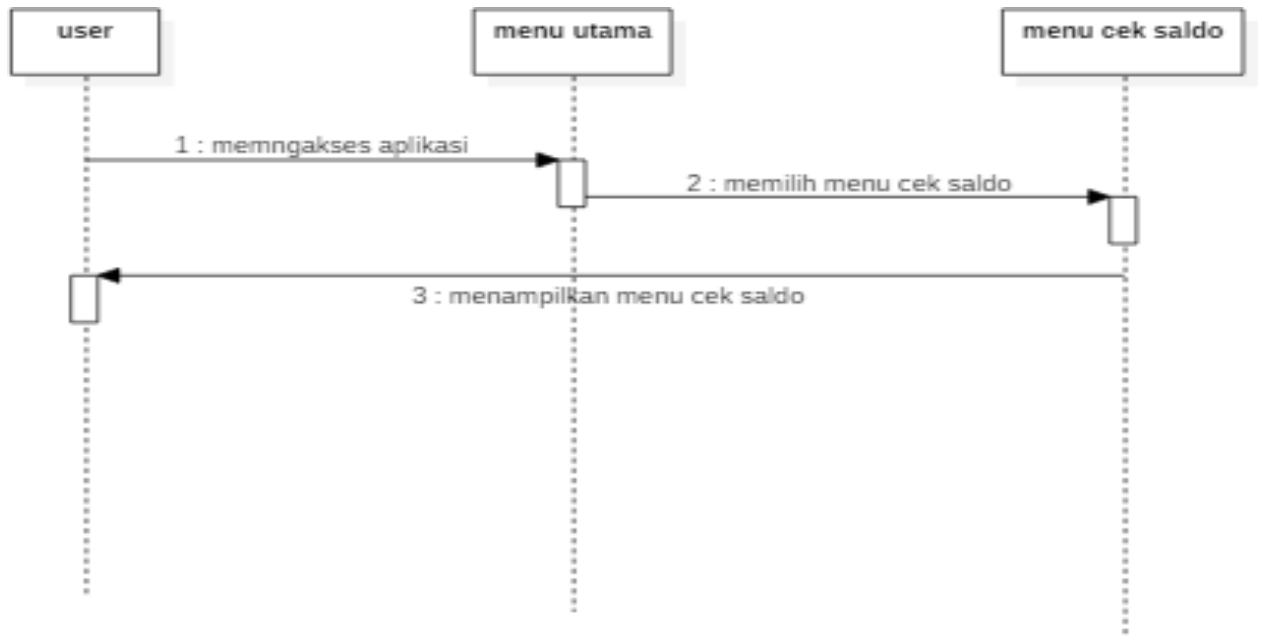

Gambar 4.12 Sequence diagram menu cek saldo Penulis (2019)

Pada diagram sequence ini menu cek saldo. Pengguna User membuka aplikasi dan sistem akan menampilkan menu utama, jika user memilih menu cek saldo maka sistem akan menampilkan menu cek saldo.

\subsubsection{Diagram Sequence Menu Cek Hutang}

Pada diagram sequence setelah user masuk membuka aplikasi maka sistem akan menampilkan menu utama, setelah menu utama, jika user memilih menu cicilan maka sistem akan menampilkan menu cicilan. 


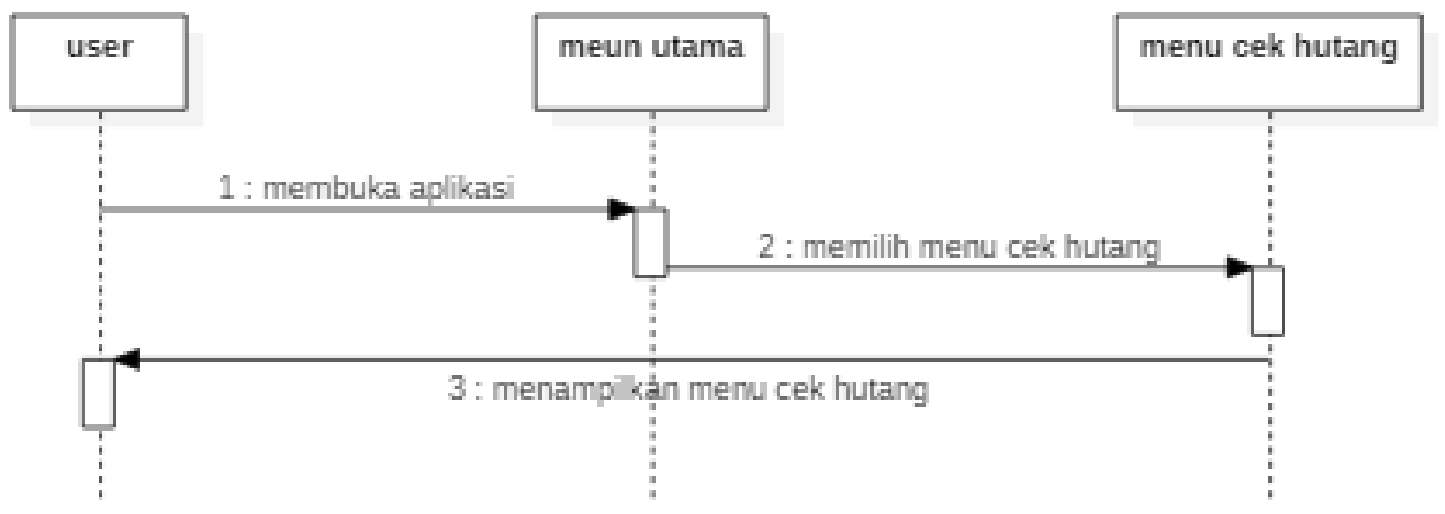

Gambar 4.13 Sequence diagram menu Cek Hutang Penulis (2019)

\subsubsection{Diagram Sequence Menu Rekapitulasi}

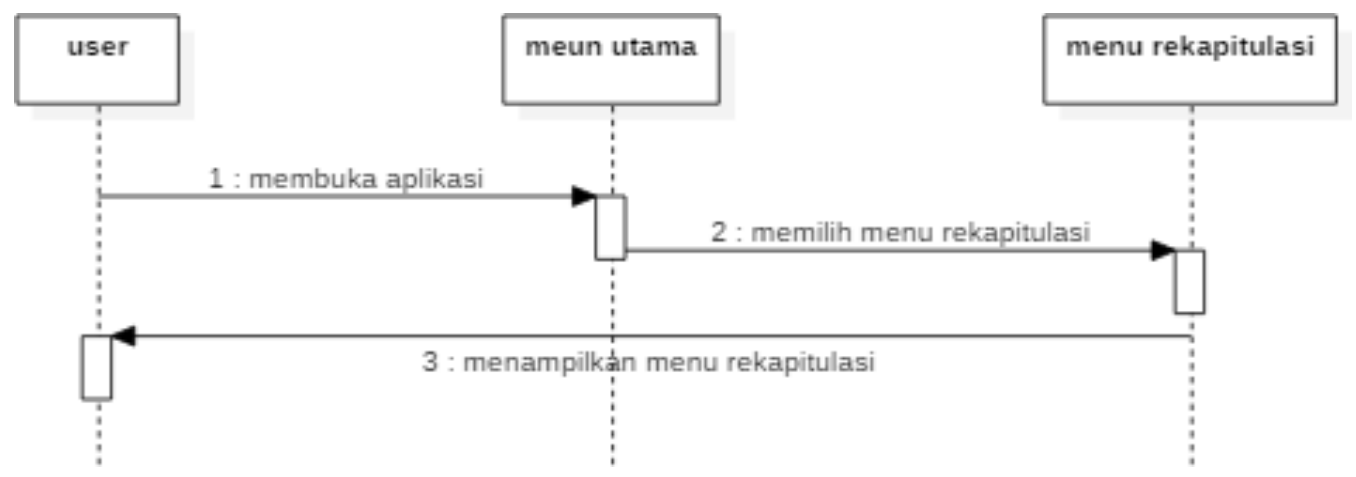

Gambar 4.14 Sequence diagram menu rekapitulasi Penulis (2019)

Pada diagram sequence ini user membuka aplikasi maka sistem akan menampilkan menu utama setelah user memilih menu rekapitulasi sistem akan menampilkan menu rekapitulasi.

\subsubsection{Diagram Sequence Menu Headline}

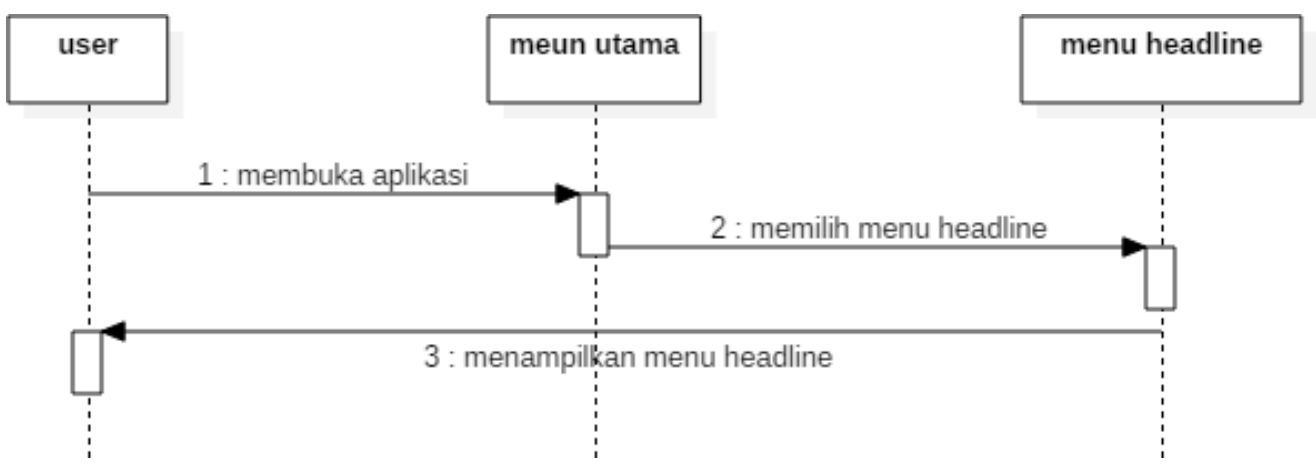

Gambar 4.15 Sequence diagram menu headlin 
Pada diagram sequence ini user membuka aplikasi maka sistem akan menampilkan menu utama setelah user

\subsubsection{Diagram Sequence Menu Pengajuan}

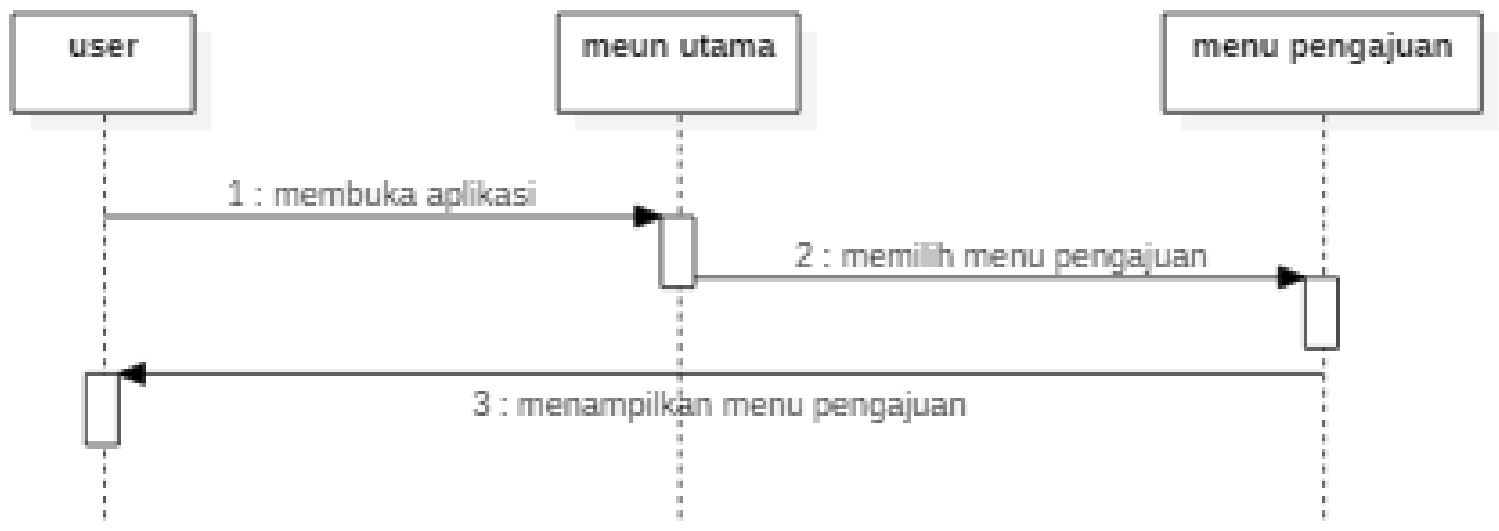

Gambar 4.16 Sequence diagram menu Penga

Pada diagram sequence ini user membuka aplikasi maka sistem akan menampilkan menu utama setelah user memilih menu Pengajuan sistem akan menampilkan menu pengajuan.

\subsubsection{Diagram Sequence Menu Keluar}

Pada diagram sequence ini user membuka aplikasi maka sistem akan menampilkan menu utama setelah user memilih menu Pengajuan sistem akan menampilkan menu pengajuan. 


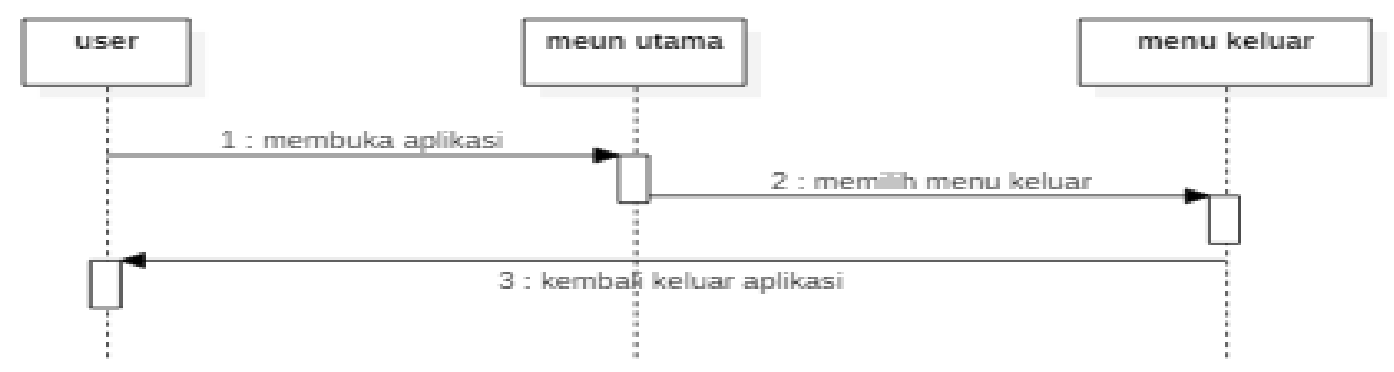

Gambar 4.17 Sequence diagram menu keluar Penulis (2019)

\subsection{Tampilan Antar Muka}

Storyboard adalah rancangan awal dari sebuah aplikasi yang akan dibangun sehingga dapat memberikan gambaran dari awal aplikasi yang dihasilkan. Dengan menganalisa apakah posisi sudah sesuai dan sudah dapat dikenali oleh pengguna.

\subsubsection{Storyboard login}

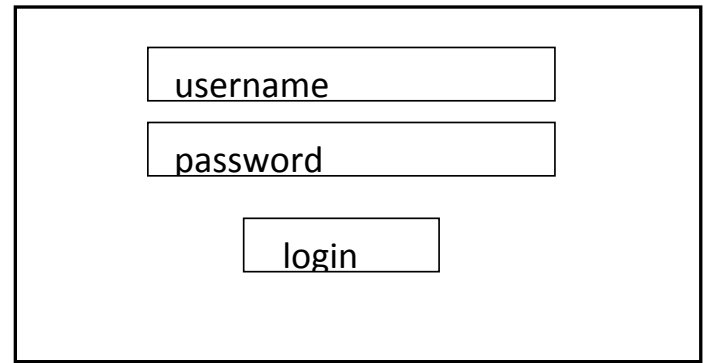

Gambar 4.18 Tampilan storyboard Halaman login Penulis (2019)

\subsubsection{Storyboard Menu Utama}

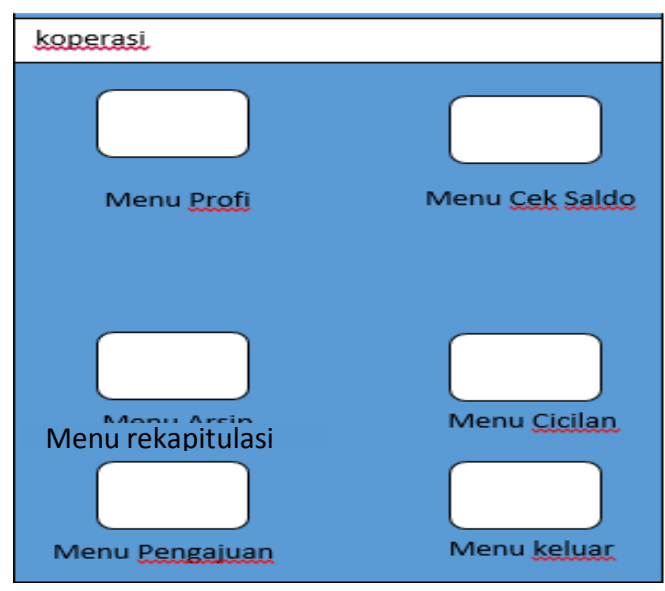

Gambar 4.19 Tampilan storyboard Halaman Menu Utama Penulis (2019)

\subsubsection{Storyboard Tampilan Menu Profil}

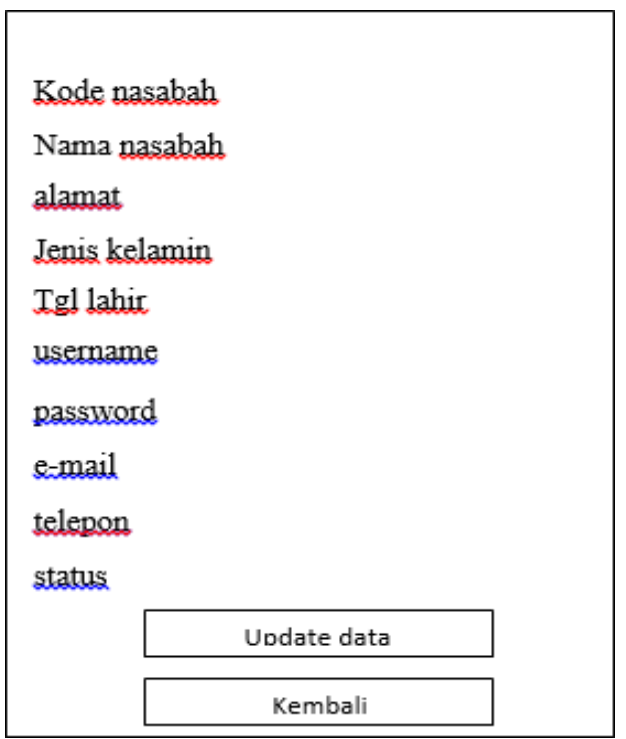

Gambar 4.20 Tampilan storyboard Profil Penulis (2019)

\subsubsection{Storyboard Tampilan Menu Cek Saldo}

\begin{tabular}{l} 
Kode tabungan \\
Iol tabungan \\
jam \\
kategori \\
nominal \\
catatan \\
nasabah \\
\\
\\
kembali \\
\hline
\end{tabular}

Gambar 4.21 Tampilan storyboard Cek Saldo Penulis (2019) 


\subsubsection{Storyboard Tampilan Menu Pengajuan}

Transaksi pembayaran hutang 1

Transaksi pembayaran hutang 2

Transaksi pembayaran hutang 3

Gambar 4.22 Tampilan storyboard Pengajuan Penulis (2019)

\subsubsection{Storyboard Tampilan Menu Cek} hutang

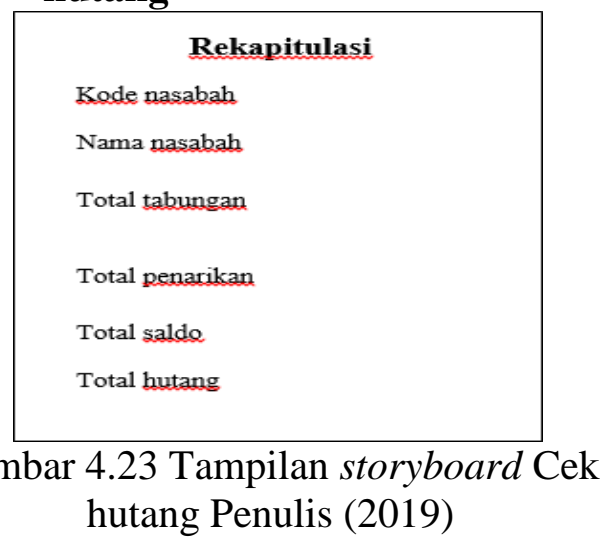

4.4.7 Storyboard Tampilan Menu Headline

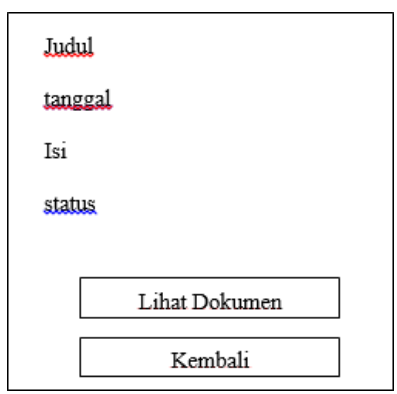

Gambar 4.24 Tampilan storyboard Headline Penulis (2019)

\subsubsection{Storyboard Tampilan Menu Rekapitulasi}

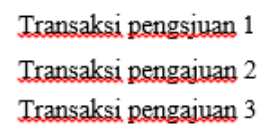

Gambar 4.25 Tampilan storyboard Rekapitulasi Penulis (2019)

\subsection{Perancangan Database \\ Perancangan database adalah} suatu bentuk hal yang penting. Database berfungsi sebagai penyimpan data, data dalam database diolah menjadi data yang diinginkan perancangan database yang diusulkan sebagai berikut:

\subsubsection{Tabel Data Nasabah}

Struktur sebagai berikut: 
Table 4.2 Struktur Tabel Nasabah

\begin{tabular}{|l|l|l|l|l|}
\hline No & Field & Jenis & Ukuran & Keterangan \\
\hline 1 & Kode nasabah & Varchar & 15 & Kode nasabah \\
\hline 2 & Nama nasabah & Varchar & 30 & Nama nasabah \\
\hline 3 & Alamat & Text & - & Alamat nasabah \\
\hline 4 & Jenis kelamin & Varchar & 15 & Jenis kelamin \\
\hline 5 & Tgl lahir & Date & - & Tanggal lahir nasabah \\
\hline 6 & Username & Varchar & 30 & Nama pengguna \\
\hline 7 & Password & Varchar & 15 & Password \\
\hline 8 & Email & Varchar & 30 & Email nasabah \\
\hline 9 & Telepon & Varchar & 15 & Telepon \\
\hline 10 & Status & Varchar & 15 & Status nasabah \\
\hline
\end{tabular}

\subsubsection{Tabel Data User}

Struktur sebagai berikut :

Table 4.3 Struktur Tabel User

\begin{tabular}{|l|l|l|l|l|}
\hline No & Field & Jenis & Ukuran & Keterangan \\
\hline 1 & Kode user & Varchar & 15 & Kode admin \\
\hline 2 & Nama user & Varchar & 30 & Nama admin \\
\hline 3 & Email & Varchar & 30 & Alamat admin \\
\hline 4 & telepon & Varchar & 15 & Telepon \\
\hline 5 & Bagian & Varchar & 15 & Bagian admin \\
\hline 6 & Username & Varchar & 30 & Nama pengguna \\
\hline 7 & Password & Varchar & 15 & Password \\
\hline 8 & Status & Varchar & 15 & Status admin \\
\hline
\end{tabular}

\subsubsection{Tabel Data Berita}

Struktur sebagai berikut :

Table 4.4 Struktur Tabel Berita

\begin{tabular}{|l|l|l|l|l|}
\hline No & Field & Jenis & Ukuran & Keterangan \\
\hline 1 & Kode berita & Varchar & 15 & Kode berita \\
\hline 2 & Judul & Varchar & 30 & Judul \\
\hline 3 & tanggal & Date & - & Tanggal berita \\
\hline 4 & Isi & Text & - & Isi berita \\
\hline 5 & Link & Text & - & Link \\
\hline 6 & Status & Varchar & 30 & Status \\
\hline 7 & Dokumen & Varchar & 50 & dokumen \\
\hline
\end{tabular}




\subsubsection{Tabel Data Pengajuan}

Struktur sebagai berikut :

Table 4.5 Struktur Tabel pengajuan

\begin{tabular}{|l|l|l|l|l|}
\hline No & Field & Jenis & Ukuran & Keterangan \\
\hline 1 & Kode pengajuan & Varchar & 15 & Kode nasabah \\
\hline 2 & Tgl pengajuan & Date & - & Tgl pengajuan \\
\hline 3 & Jam & Time & - & Waktu pengajuan \\
\hline 4 & Kode nasabah & varchar & 15 & Kode nasabah \\
\hline 5 & nominal & Int & 15 & Nominal pengajuan \\
\hline 6 & Alasan pinjaman & Text & - & Alasan \\
\hline 7 & Status & varchar & 15 & Status \\
\hline 8 & Catatan & Text & - & Catatan \\
\hline 9 & Tenor & varchar & 15 & Tenor \\
\hline 10 & Cicilan perbulan & Int & 15 & Cicilan pengajuan \\
\hline 11 & Tgl jatuh tempo & Date & - & $\begin{array}{l}\text { Tgl jatuh } \\
\text { pengajuan }\end{array}$ \\
& & & & \\
\hline
\end{tabular}

\subsubsection{Tabel Data Tabungan}

Struktur sebagai berikut :

Table 4.6 Struktur Tabel Tabungan

\begin{tabular}{|l|l|l|l|l|}
\hline No & Field & Jenis & Ukuran & Keterangan \\
\hline 1 & Kode tabungan & Varchar & 15 & Kode tabungan \\
\hline 2 & Tgl tabungan & Date & - & Tgl tabungan \\
\hline 3 & jam & Time & - & Jam tabungan \\
\hline 4 & kategori & varchar & 15 & Kategori \\
\hline 5 & nominal & Int & 15 & Nominal tabungan \\
\hline 6 & catatan & Text & - & Catatan \\
\hline 7 & Kode nasabah & varchar & 15 & kode nasabah \\
\hline
\end{tabular}

\subsubsection{Tabel Data Penarikan}

Struktur sebagai berikut :

Table 4.7 Struktur Tabel Penarikan

\begin{tabular}{|l|l|l|l|l|}
\hline No & Field & Jenis & Ukuran & Keterangan \\
\hline 1 & Kode penarikan & Varchar & 15 & Kode penarikan \\
\hline 2 & Tgl penarikan & Date & - & Tgl penarikan \\
\hline 3 & jam & Time & - & Jam \\
\hline 4 & Kode nasabah & varchar & 15 & Kode nasabah \\
\hline 5 & nominal & Int & 15 & Nominal \\
\hline 6 & catatan & Text & - & Catatan \\
\hline 7 & status & varchar & 15 & Status \\
\hline
\end{tabular}




\subsubsection{Tabel Data Utang}

Struktur sebagai berikut:

Table 4.8 Struktur Tabel utang

\begin{tabular}{|l|l|l|l|l|}
\hline No & Field & Jenis & Ukuran & keterangan \\
\hline 1 & Kode utang & Varchar & 15 & Kode utang \\
\hline 2 & Tgl utang & Date & - & Tgl utang \\
\hline 3 & jam & Time & - & Jam \\
\hline 4 & Kode nasabah & varchar & 15 & Kode nasabah \\
\hline 5 & nominal & Int & 15 & nominal \\
\hline 6 & catatan & Text & - & catatan \\
\hline
\end{tabular}

\subsubsection{Tabel Data Admin}

Struktur sebagai berikut :

Table 4.9 Struktur Tabel Admin

\begin{tabular}{|l|l|l|l|l|}
\hline No & Field & Jenis & Ukuran & keterangan \\
\hline 1 & Kode admin & Varchar & 15 & Kode admin \\
\hline 2 & Username & Varchar & 25 & username \\
\hline 3 & Password & Varchar & 25 & password \\
\hline 4 & Telepon & varchar & 15 & telepon \\
\hline 5 & Email & varchar & 50 & email \\
\hline 6 & gambar & varcar & 50 & gambar \\
\hline 7 & Status & Enum & $\begin{array}{l}\text { (“aktif” } \\
\text { “tidak aktif”) }\end{array}$ & status \\
\hline
\end{tabular}

\subsection{Implementasi}

Tahap implementasi adalah tahapan dimana pembangunan suatu aplikasi dari keseluruhan perancangan sistem yang sudah dibuat, sehingga menghasilkan sistem yang sesuai dengan kebutuhan dantujuan awal yang telah ditetapkan.

\subsubsection{Implementasi antar Muka Pengguna (Admin)}

\subsubsection{Tampilan Menu Login (Admin)}

Pada menu ini hanya bisa di akses oleh admin yang memiliki hak prioritas atas ketentuan dalam koperasi yaitu admin teller atau menejer yang menjalankan sebuah sistem yang ada di menu localhost/koperasi/index.php dengan memasukkan username id dan password di tunjukkan pada gambar sebagai berikut: 


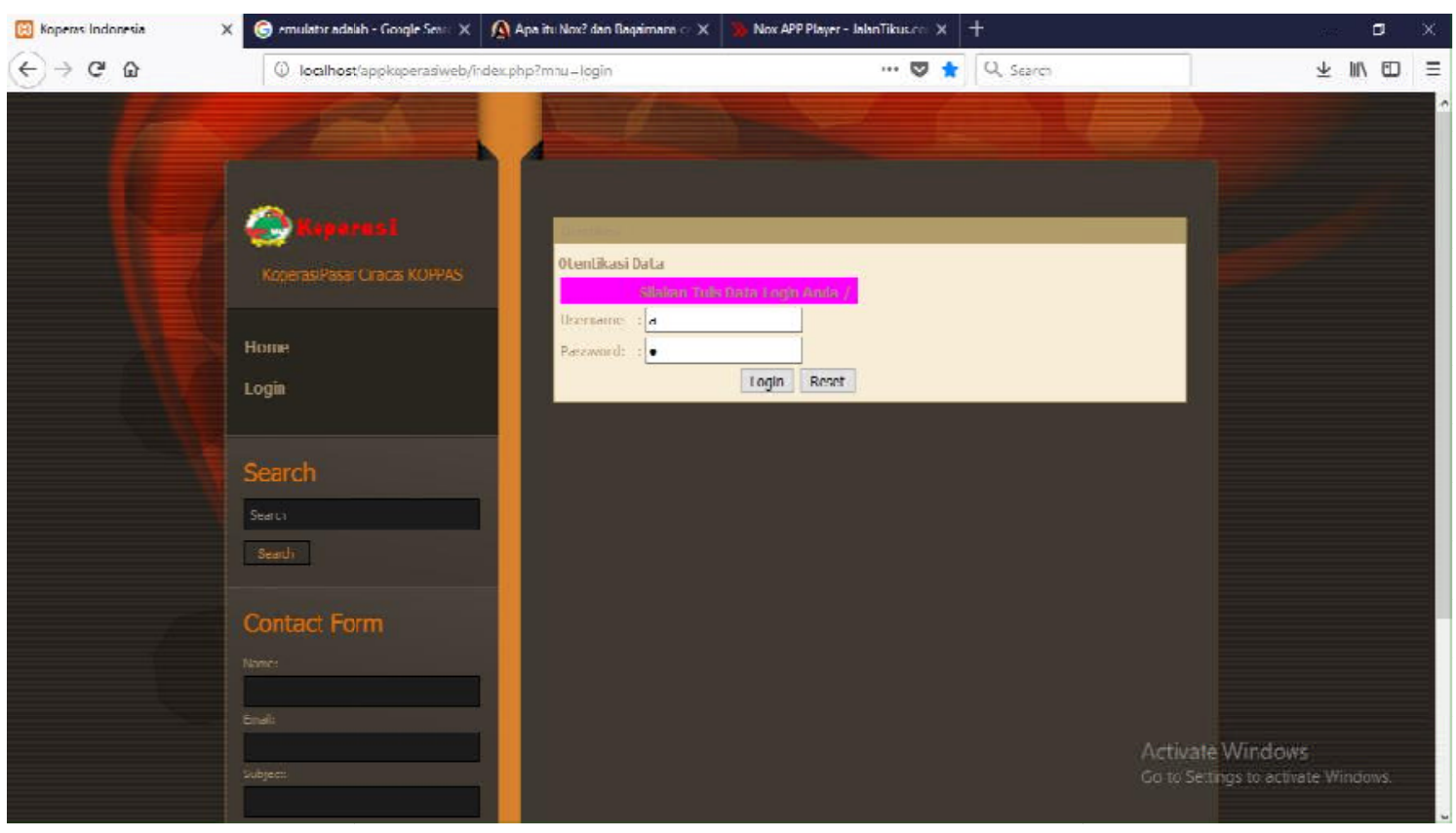

Gambar 4.26 Tampilan Menu Login admin Penulis (2019)

\subsubsection{Tampilan Menu Admin}

Hasil implementasi pendaftaran user admin mengisi daftar login terlebih dahulu untuk mengontrol hak akses admin sistem koperasi yang ditampilkan sebagai berikut:

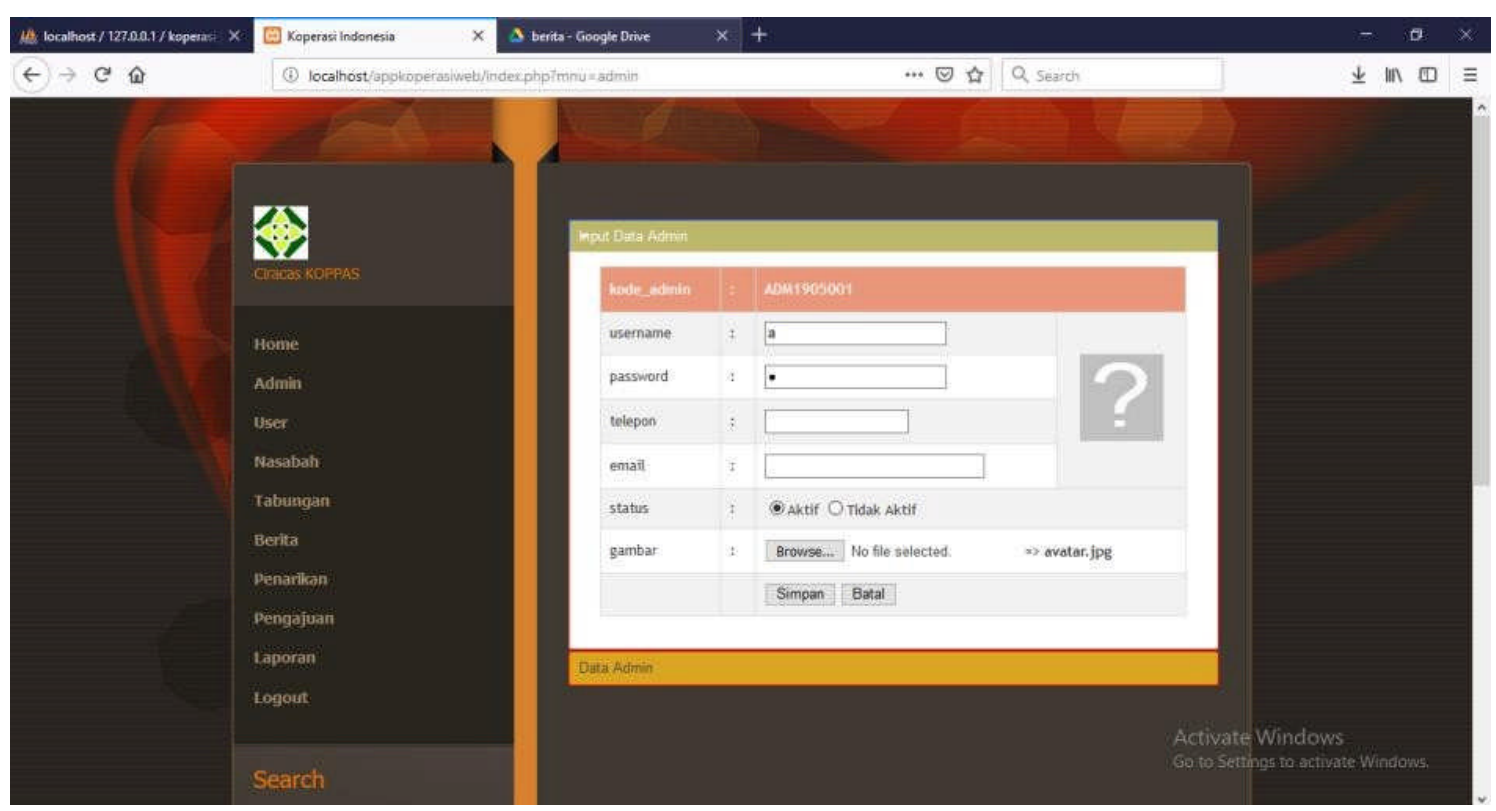

Gambar 4.27 Tampilan Menu Admin 
4.6.1.3 Tampilan Menu Nasabah

Hasil implementasi pada menu nasabah ini digunakan untuk mendaftar nama nasabah digunakan untuk daftar dan menghapus anggota yang ditampilkan sebagai berikut:

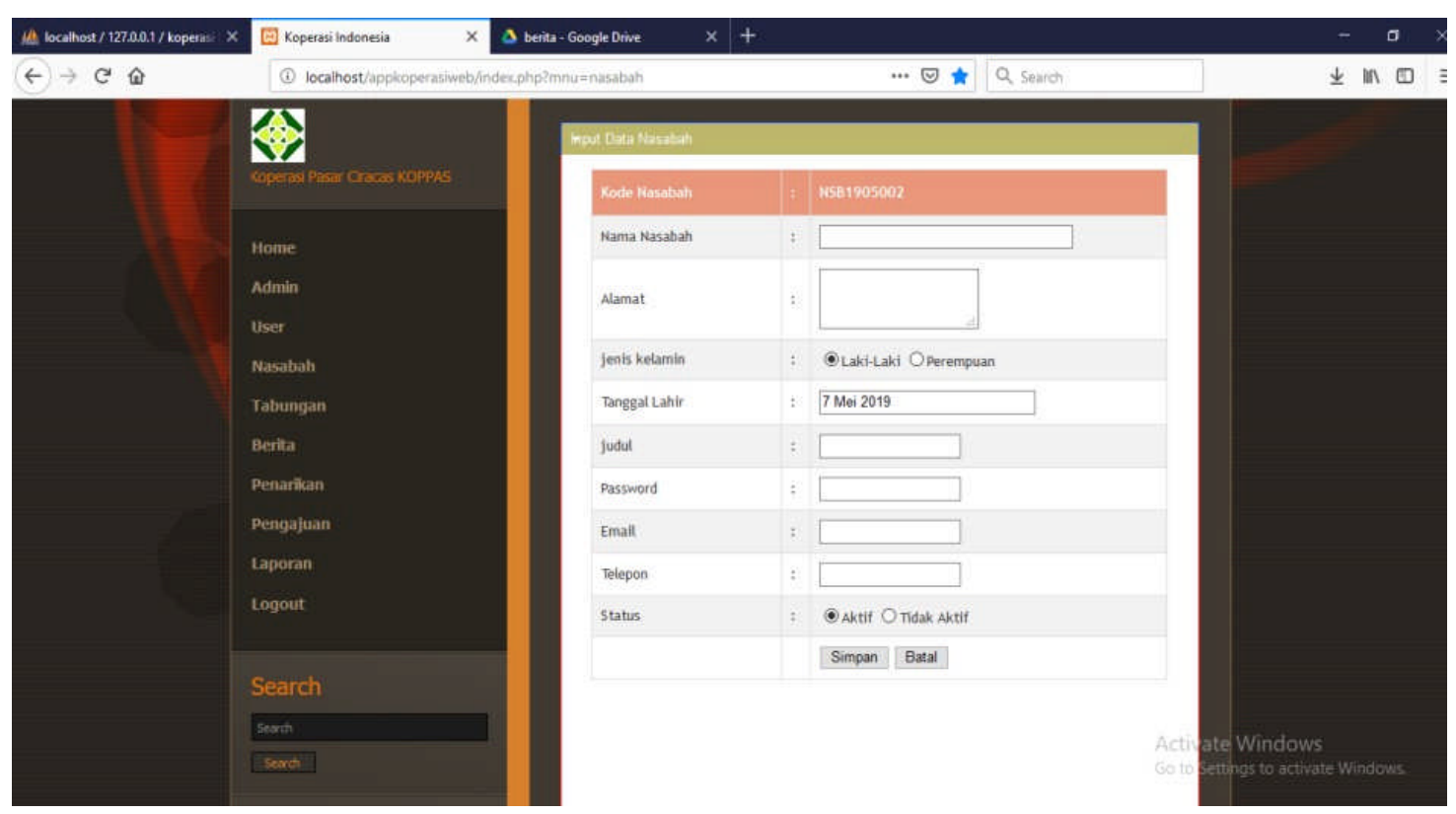

Gambar 4.28 Tampilan Menu Nasabah Penulis (2019)

\subsubsection{Tampilan Menu Tabungan}

Hasil implementasi pada menu

Tabungan ini digunakan untuk mengetahui dan menginput data tabungan anggota koperasi yang ditampilkan sebagai berikut:

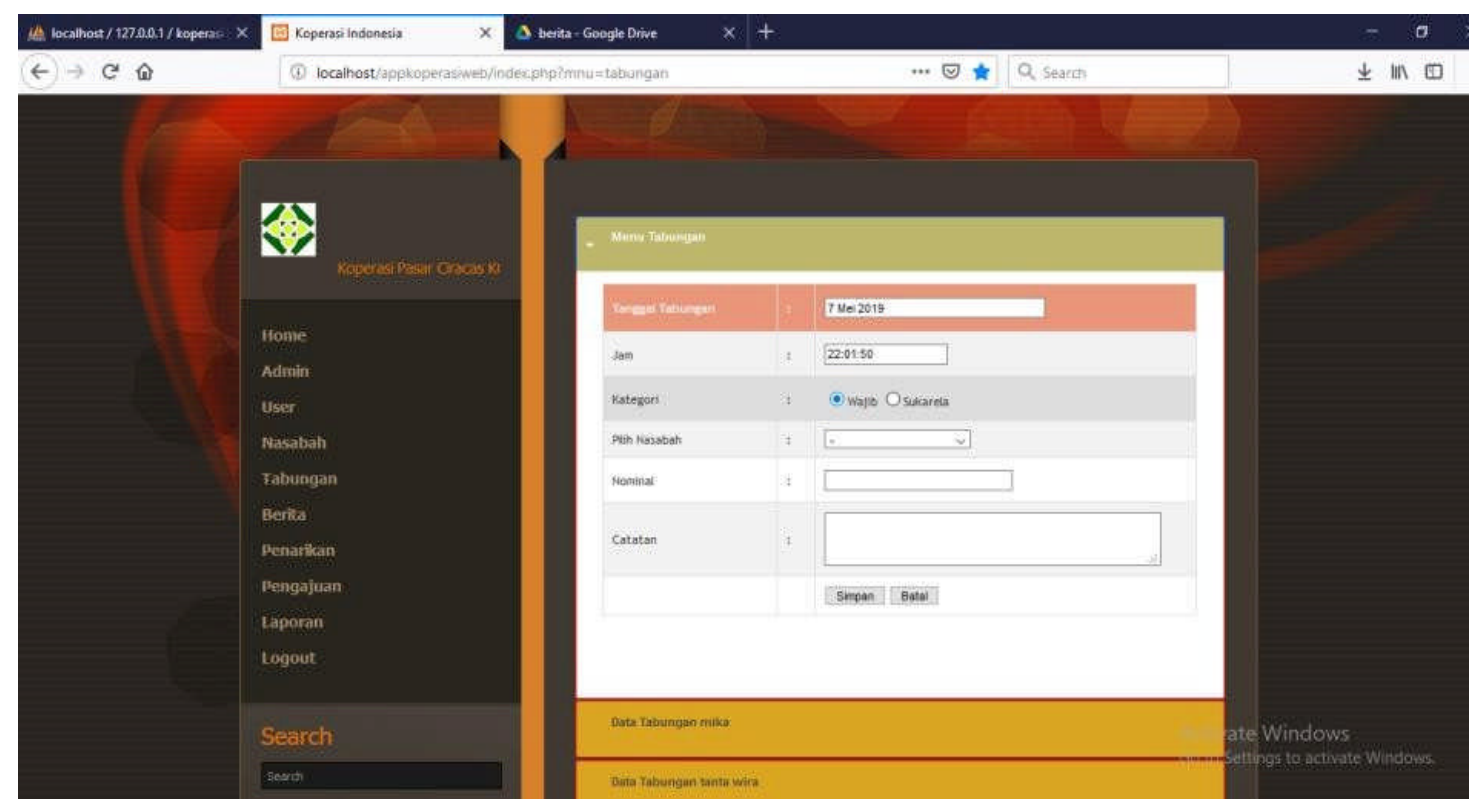

Gambar 4.29 Tampilan Menu Tabungan Penulis (2019) 


\subsubsection{Tampilan Menu Utang}

Hasil implementasi pada menu utang ini digunakan untuk mengetahui dan menginput data utang anggota koperasi yang ditampilkan sebagai berikut:

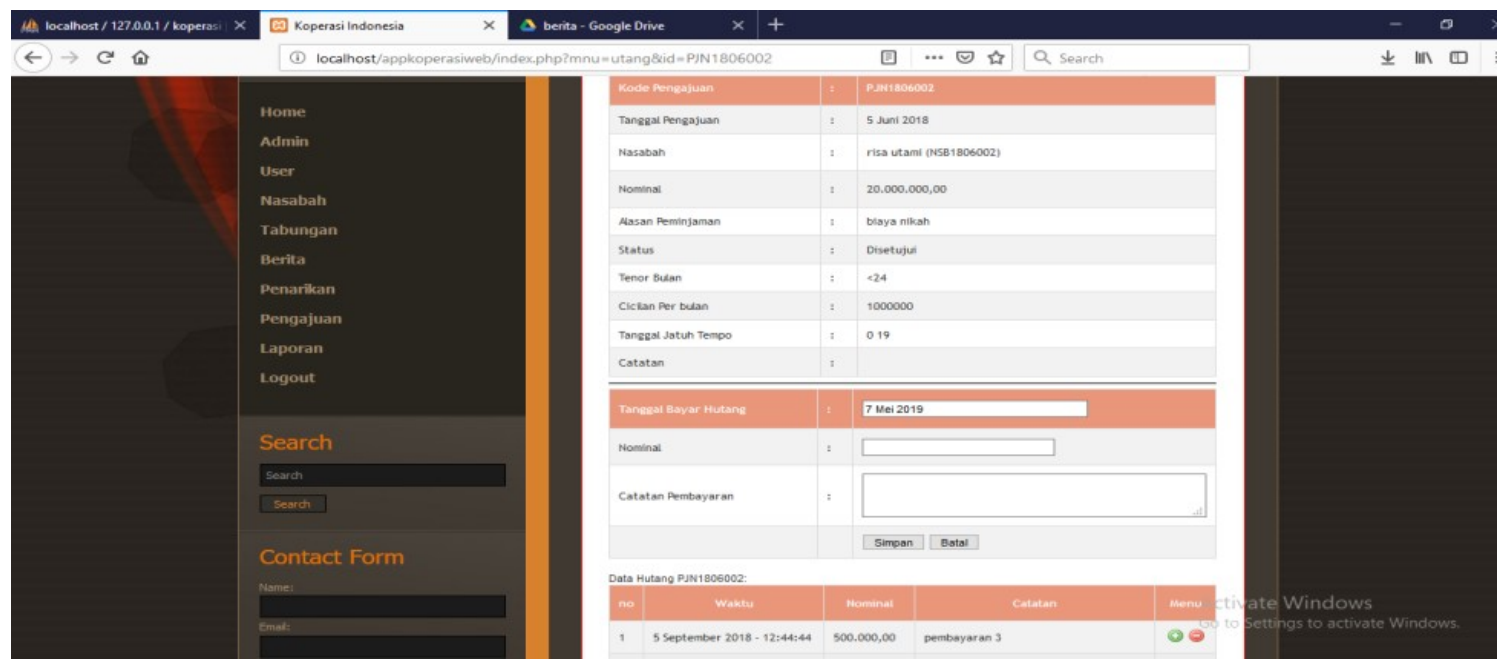

Gambar 4.30 Tampilan Menu Utang Penulis (2019)

\subsubsection{Tampilan Menu Pengajuan mengetahui dan menginput data}

Hasil implementasi pada menu pengajuan hutang anggota koperasi yang pengajuan ini digunakan untuk ditampilkan sebagai berikut:

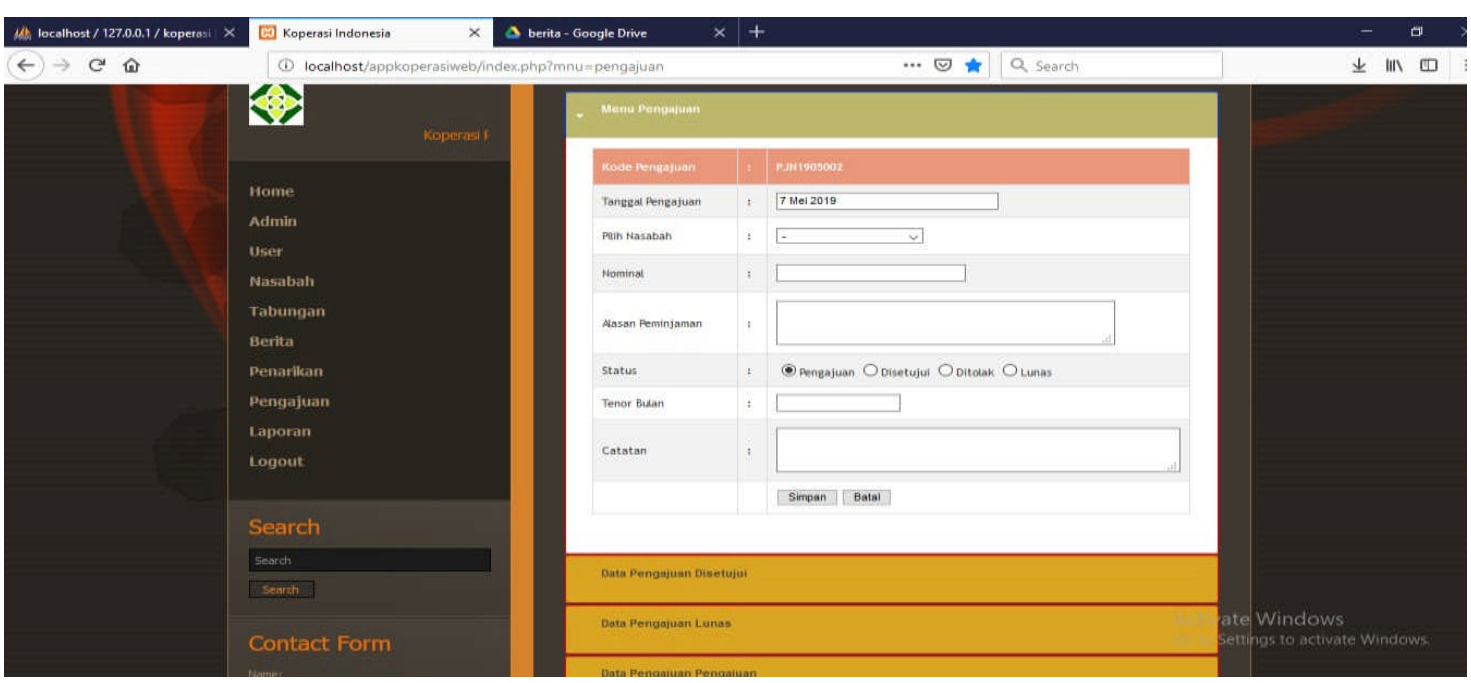

Gambar 4.31 Tampilan Menu Pengajuan Penulis (2019)

\subsubsection{Tampilan Menu Penarikan}

Hasil implementasi pada menu penarikan ini digunakan untuk mengetahui dan menginput data penarikan tabungan yang anggota koperasi miliki yang ditampilkan sebagai berikut: 


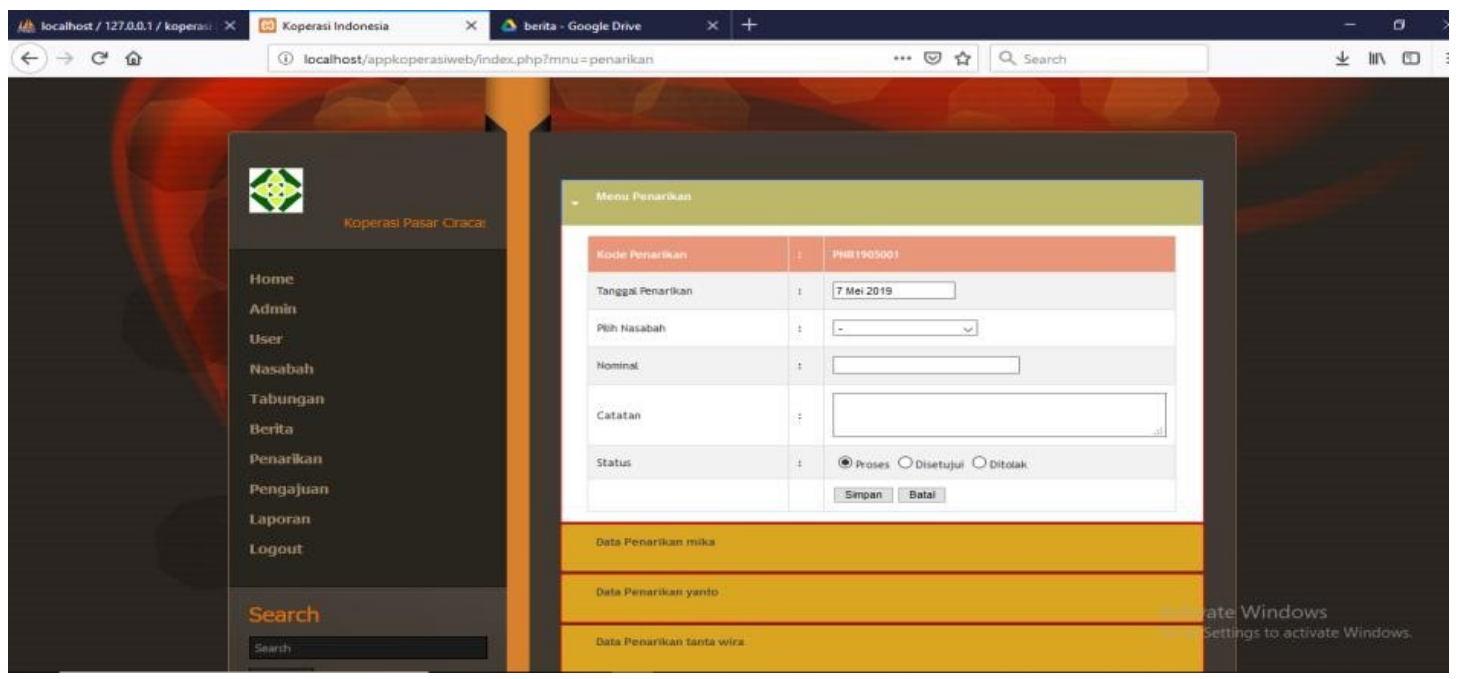

Gambar 4.32 Tampilan aplikasi Menu Penarikan Penulis (2019)

\subsubsection{Halaman Database pada Menu PhpMyAdmin}

Hasil implementasi dari halaman database menu PhpMyAdmin digunakan untuk memasukkan database secara online

padahttp://localhost/phpmyadmin/ db_structure.php? server $=1 \& d b=d b \_k o p$ erasi. Yang ditampilkan sebagai berikut:

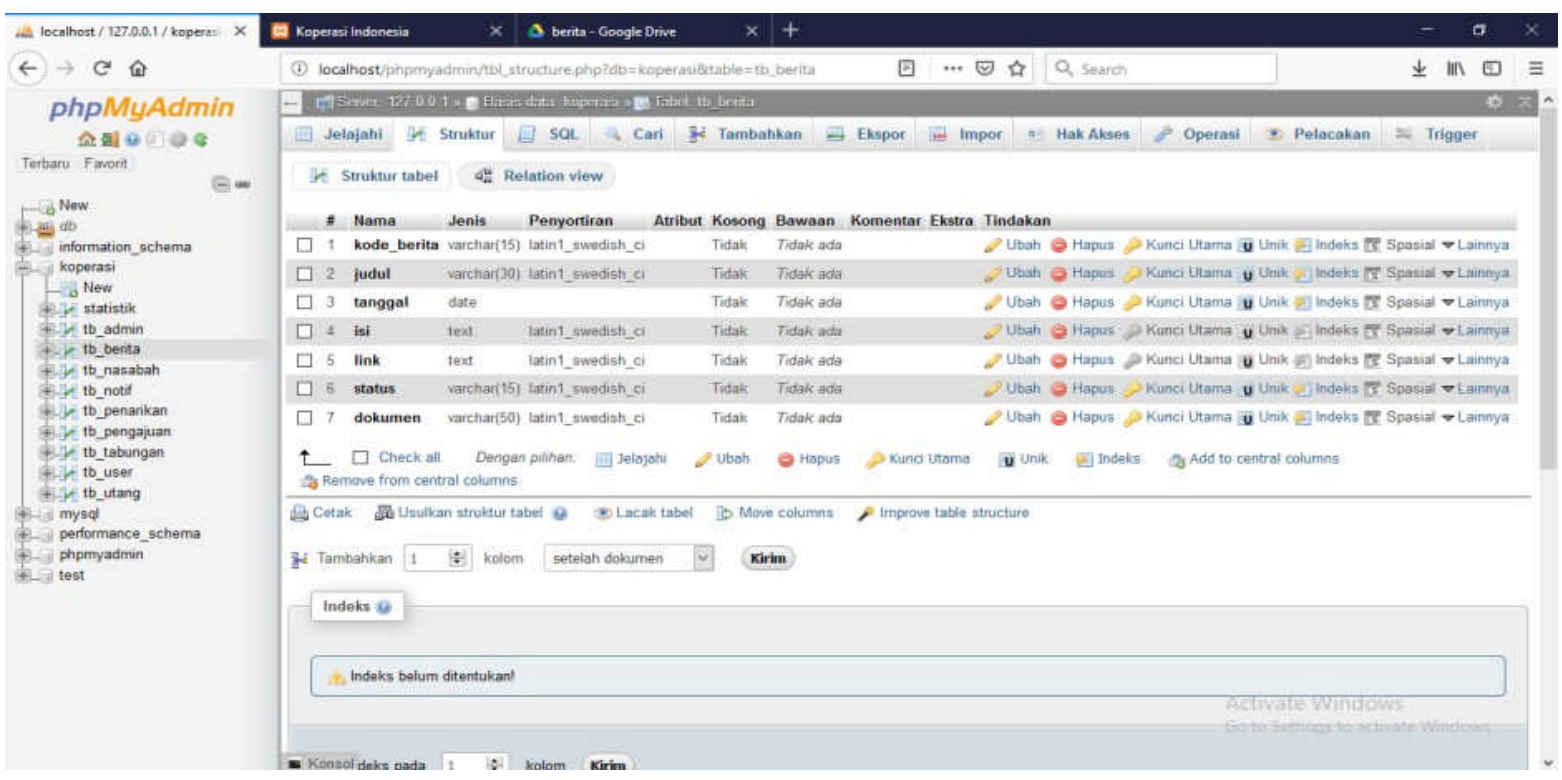

Gambar 4.33 Tampilan Data Koperasi pada database localhost Koperasi Pasar Cir

\subsubsection{Implementasi Antar Muka Untuk Aplikasi Pengguna}

Aplikasi ini terdiri dari beberapa antar muka dengan tampilan menu utama, menu profil, menu cek saldo, menu cek hutang, menu pinjaman, menu arsip, dan menu keluar.

\subsubsection{LOGIN}

Pertama masuk aplikasi anggota akan ditampilkan menu login anggota yang memiliki akun diharapkan 
memasukkan akun login anggota bisa. Masuk anggota tersebut sebagai berikut:

\subsubsection{Tampilan Menu Utama}

Pada menu utama anggota dapat memilih menu yang di inginkan dengan menu menu yang di tampilkan oleh sistem, menu profil adalah akun dari pengguna sendiri dengan koperasi, menu cek saldo menampilkan pertransakasi saldo anggota sehingga anggota bisa melihat transaksi terakhir, menu cek hutang menampilkan pembayaran cicilan anggota yang sudah dibayarkan pertransaksi, menu arsip digunakan untuk menampilkan reminder anggota sesuai transaksi baik saldo tabungan dan saldo hutang tunggakan anggota kepada koperasi, menu pinjaman menampilkan pengajuan peminjaman anggota, menu keluar untuk keluar aplikasi.

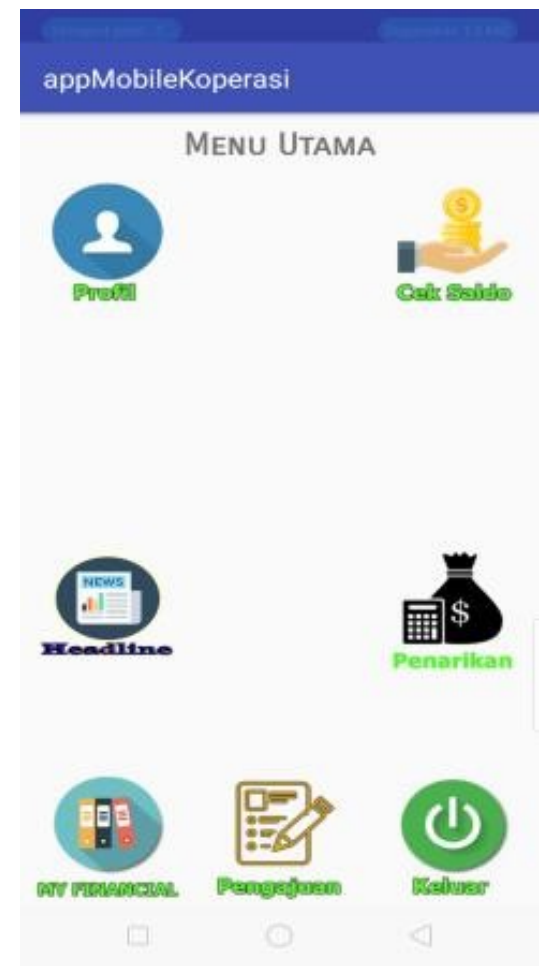

Gambar 4.36 Tampilan Menu Utama

Penulis (2019)

\subsubsection{Tampilan Menu Cek saldo Pada menu ini setiap anggota}

yang meniliki akun dapat melihat data keuangan pertransaksi melalui aplikasi koperasi anggota ditampilkan dengan memilih menu cek saldo sebagai berikut:

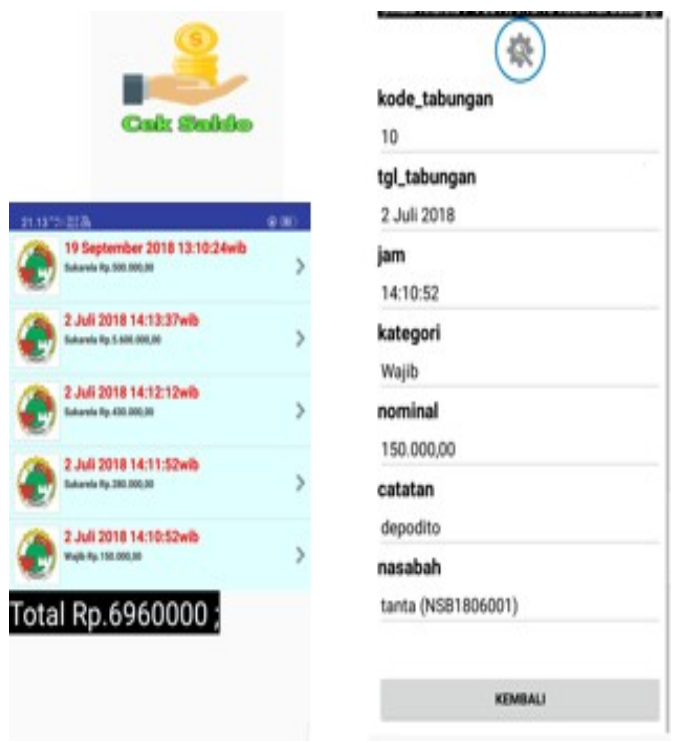

Gambar 4.37 Tampilan Aplikasi Menu Cek Saldo Penulis (2019)

\subsubsection{Tampilan Profil}

Menu ini menampilkan profil anggota yang bisa diubah oleh anggota, anggota memilih aplikasi menu profil lalu akan memunculkan tampilan sebagai berikut :

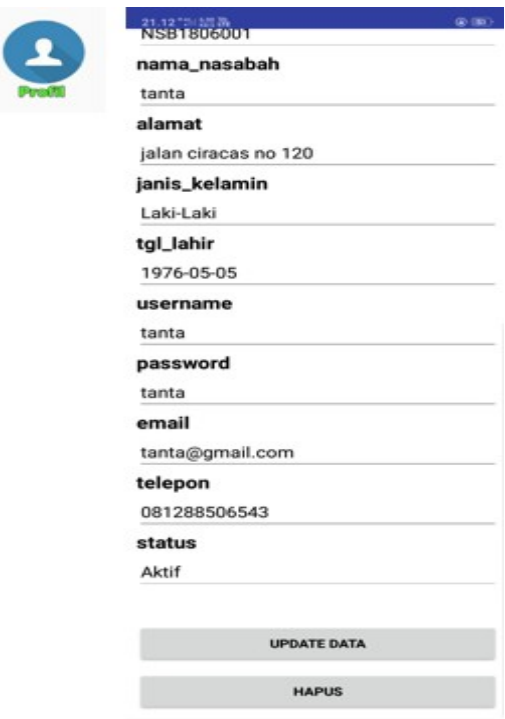

Gambar 4.38 Tampilan Aplikasi Menu Profil Penulis (2019) 


\subsubsection{Tampilan Menu Pengajuan}

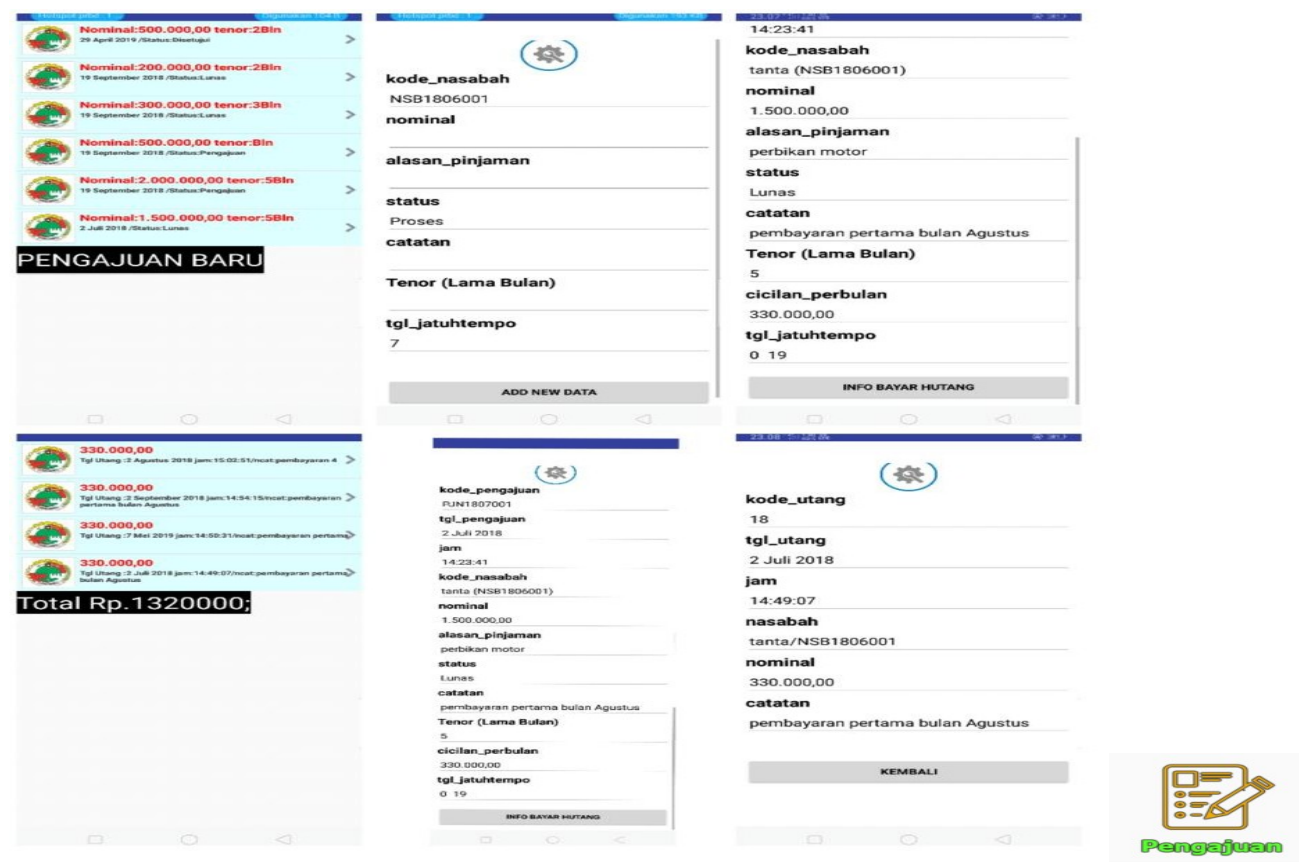

Gambar 4.39 Tampilan Aplikasi Menu Pengajuan Penulis (2019)

Menu ini ditujukan untuk anggota melihat dan mengajukan pengajuan hutang serta info bayar hutang anggota yang telah lakukan transaksi, anggota memilih aplikasi menu pengajuan secara langsung seperti ditampilkan pada gambar diatas.

\subsubsection{Tampilan Menu Rekapitulasi}
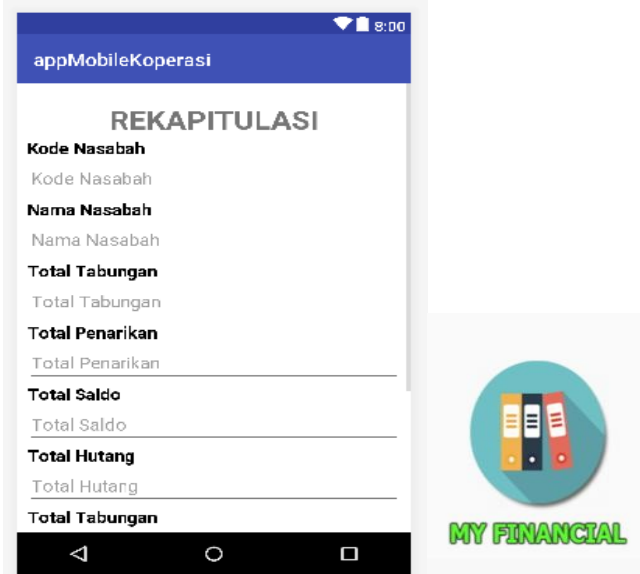

Gambar 4.40 Tampilan Aplikasi Menu Rekapitulasi Penulis (2019)
Pada menu ini anggota mengontrol rekapitulasi keuangan dari berapa transaksi yang telah dilakukan baik penarikan, hutang, tabungan, dan total dari keuangan anggota. Anggota memilih menu rekapitulasi, kemudian akan ditampilkan sebagai diatas.

\subsubsection{Tampilan Menu Penarikan}

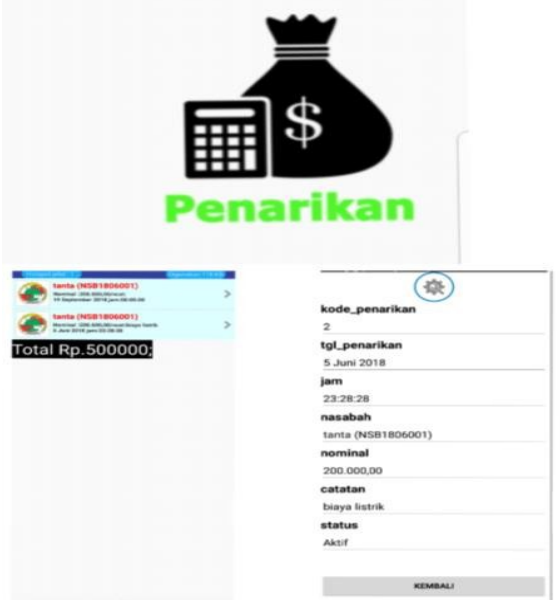

Gambar 4.41 Tampilan Aplikasi Menu Penarikan Penulis (2019) 
Menu ini ditujukan untuk anggota melihat Transaksi Penarikan tabungan yang telah di lakukan selama ini, anggota memilih aplikasi menu penarikan secara langsung seperti ditampilkan pada gambar diatas.

\subsubsection{Tampilan Menu Headline}

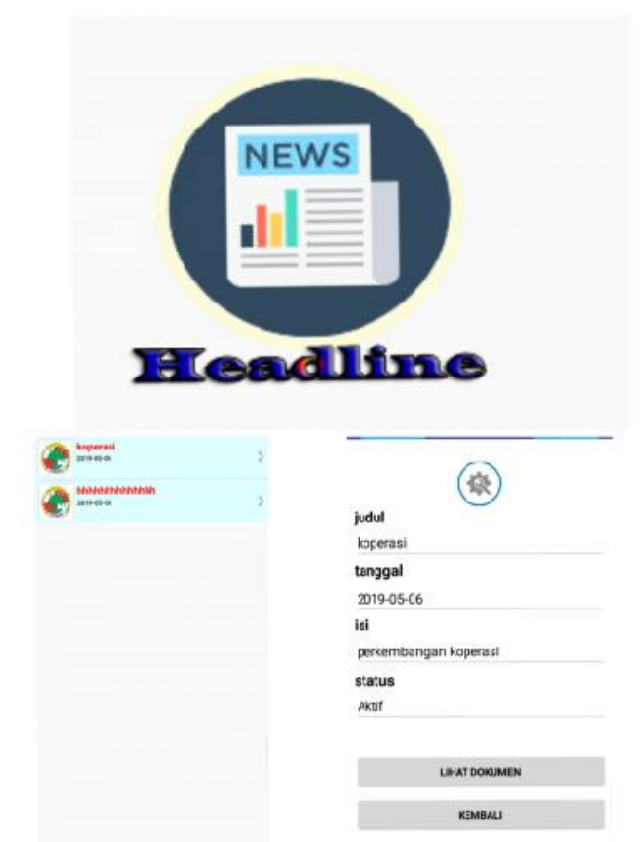

Gambar 4.42 Tampilan Aplikasi Menu Headline

Menu ini ditujukan untuk anggota melihat Headline terbaru dari koperasi yang di lakukan dengan menyertakan dokumen berita pada aplikasi , anggota memilih aplikasi menu Headline akan secara langsung seperti ditampilkan pada gambar diatas.

\subsection{Kesimpulan}

Adapun kesimpulan dalam pembuatan aplikasi koperasi pasar ciracas ini yang dibuat sebagai berikut :

1. Menghasilkan rancangan sistem informasi koperasi dengan menggunakan aplikasi android yang menggunakan mysql sebagai databasenya.

2. Menjadikan aplikasi ini menjadi lebih efisien dan efektif bagi anggota untuk mengetahui informasi saldo dan piutang serta reminder untuk setiap anggota yang sudah mengaktifkan aplikasi koperasi.

3. Membuat sistem informasi yang realtime terhubung dengan komputer Admin dan aplikasi pengguna sehingga dapat terintegerasi secara online.

\subsection{Saran}

Berdasarkan hasil dari aplikasi koperasi pasar ciracas maka penulis memberikan saran sebagai berikut :

1. Diharapkan adanya pengembangan dari aplikasi koperasi tersebut dengan menampilkan menu lebih lanjut.

2. Setiap anggota dapat memahami dan membagi informasi kepada anggota lain dengan sistem yang terkomputerisasi saat ini melalui sosialisasi dari admin atau staff koperasi tersebut.

3. Perlu adanya pemeriksaan dan pemeliharaan secara rutin agar sistem dan aplikasi dapat bersinkronisasi dengan baik 


\section{DAFTAR PUSTAKA}

Khadir, Abdul dan Triwahyuni, Terra CH., Pengenalan Teknologi Informasi, ANDI, Yogyakarta, 2012.

Murya, Yosef, Pemrograman Android Blackbox, Jasakom, 2014

Pratama, I Putu Agus Eka, Sistem Informasi dan Implementasinya, Informatika, Bandung, 2014.

Rawung, Frangky buku pintar APLIKASI SMS dengan PHP dan MySQL, PENERBIT GAVA MEDIA, Yogyakarta, 2017.

Riyanto, Membuat Sendiri Aplikasi Mobile GIS : Platform Java ME, Bleckberry Dan Android, ANDI, Yogyakarta 2010

Safaaat H, Nazrudin, Aplikasi Berbasis Android, Informatika, Bandung, 2015.

Safaaat H, nazrudin, Android : Pemrograman Aplikasi Mobile Smartphone Dan Tablet PC Berbasis Android, Informatika, Bandung, 2014.

Subagyo. Ahmad, Manejemen Koperasi Simpan Pinjam, Mitra Wacana Media, Jakarta, 2014.

Subri, Tata, Konsep Sistem Informasi, ANDI, Yogyakarta, 2012. Sutabri, Tata, Analisis Sistem Informasi, ANDI, Yogyakarta, 2012.

Tim EMS, Belajar Pemrograman Android Berbasis Web Untuk Semua Orang, Elex Media Komputindo, Jakarta 2015.

Undang-undang RI Nomor 20 Tahun 2008 Tentang Usaha Mikro, Kecil dan Menengah \& Undang-undang RI nomor 25 Tahun 1992 Tentang Perkoperasian.

\section{JURNAL}

Anggoro, Dani, Umar, Muhammad David dan dkk, Rancangan Sistem Informasi Koperasi Simpan Pinjam Guru dan Pegawai pada Koperasi SMK MANGGALA TANGERANG, ISSN : 2089-9515, Universitas Budi Luhur Jakarta, Jakarta, 2015.

Hasan, dan Kosasi Sandy, Perancangan Sistem pengolahan Data Debitur Untuk Mengetahui Kolektibilitas Debitur, ISSN : 2302-3805, STIMIK PONTIANAK, Pontianak, 2015.

Imtihan, Khairul., Hawadiyah, Rabiatul, dan Asyari, Hasyim, Sistem Informasi Penggajian Guru Honorer menggunakan konsep

metodelogi Extreme Programming (XP) Pada SMK Bangun Bangsa, ISSN : 2302-5700, STIMIK LOMBOK, Lombok, 2017.

Rahmadi, dan Mulyani, Dwi, Model Sistem Informasi Bank Sampah Syariah/ Mikro 
Finance, ISSN 25415662, STIMIK Banjarbaru, Banjarbaru 2016

Riyanto, Andi dwi dan Kusumastuti, Galuh, Pembangunan Sistem Informasi Pengelolaan Data Pada Tabungan BANK SAMPAH “CERIA” PURWOREJO, ISSN : 1979925X, STIMIK AMIKOM

PURWOKERTO, Purwokerto, 2015.

\section{Website}

https://id.wikipedia.org/wiki/Android_(sistem_operasi). Jakarta, diakses pada tanggal 07112017 07:16 WIB

http://www.depkop.go.id/ . Jakarta, diakses pada tanggal 07112017 07:16 WIB

https://www.mysql.com/about/legal/logos.html. Jakarta, diakses pada tanggal 02112017 03.34 WIB

https://id.wikipedia.org/wiki/Koperasi Jakarta, diakses pada tanggal 02112017 03.34 WIB 
